\title{
Why Do French Engineers Find Stable Jobs Faster than PhDs?
}

\author{
David N. Margolis* and Luis Miotti ${ }^{\dagger}$
}

July 1,2020

\begin{abstract}
This paper studies why $\mathrm{PhDs}$ in France take longer to find stable jobs than engineers. Using data from CEREQ's "Génération 2004" survey, we show that job finding rates of $\mathrm{PhDs}$ are lower than those of engineers and document the differences in their observable characteristics and fields of study. We show that this phenomenon is due to multiple factors: heterogeneity in student characteristics along observable and unobservable dimensions and fields of study, directed search toward public sector positions (especially professors) among $\mathrm{PhDs}$ and, in all likelihood, reservation wages of $\mathrm{PhDs}$ for private sector jobs that are "too high" relative to their value of marginal product.
\end{abstract}

\section{Résumé}

Ce papier examine les raisons pour lesquelles les docteurs prennent plus de temps à trouver un emploi stable que les ingénieurs en France. En utilisant les données de l'enquête «Génération 2004 » du CEREQ, nous présentons les différences entre les caractéristiques observables et les domaines de spécialisation entre ingénieurs et différents types de docteur et nous démontrons que la vitesse d'insertion des docteurs est plus lente que celle des ingénieurs. Ceci s'explique par des multiples facteurs : des différences entre les caractéristiques observables et inobservables, des diplômes, les choix de domaine de spécialisation, une recherche des docteurs dirigée surtout vers des postes de fonctionnaire (surtout des postes de professeur) et un salaire de réserve qui est vraisemblablement "trop élevé" par rapport à la valeur de la productivité marginale des docteurs pour des postes dans le secteur privé.

JEL Codes / Codes JEL: J24, I23, J64

Key Words: School-to-work transition, STEM, Directed search, Wage subsidies.

Mots Clés: Insertion des jeunes, STEM, Recherche dirigée, subventions salairales, Dispositif jeunes docteurs, Crédit impôt recherche.

\footnotetext{
*Paris School of Economics, CNRS and IZA. Address: 48 boulevard Jourdan, 75014 Paris, France. E-mail: David.N.Margolis@gmail.com. ${ }^{\dagger}$ CEPN (SPC) and OST (HCERES).

The authors would like to thank Frédérique Sachwald, two anonymous referees, the comité de suivi interministerielle and participants of seminars at the Paris School of Economics, the Université Paris Est-Créteil and the Journées de Microéconomie Appliquée for helpful comments. This research was partially funded by the Ministère de l'éducation nationale, de l'enseignement supérieur et de la recherche in the context of preparation of the report "Évaluation de l'impact du dispositif « jeunes docteurs » du crédit d'impôt recherche".
} 
Titre français: Pourquoi les ingénieurs se trouvent-ils leur premier emploi stable plus rapidement que les docteurs?

Auteurs: David N. Margolis and Egidio Luis Miotti

Résumé français: Ce papier examine pourquoi les docteurs prennent plus de temps à trouver un emploi stable que les ingénieurs en France. En utilisant les données de l'enquête « Génération 2004 » du CEREQ, nous présentons les différences entre les caractéristiques observables et les domaines de spécialisation entre ingénieurs et différents types de docteur et nous démontrons que la vitesse d'insertion des docteurs est plus lente que celle des ingénieurs. Ceci s'explique par des multiples facteurs : des différences entre les caractéristiques observables et inobservables, des diplômes, les choix de domaine de spécialisation, une recherche des docteurs dirigée vers des postes de fonctionnaire (surtout des postes de professeur) et un salaire de réserve vraisemblablement "trop élevé" par rapport à la valeur de la productivité marginale des docteurs pour des postes du secteur privé.

Titre anglais: Why Do French Engineers Find Stable Jobs Faster than PhDs?

Résumé anglais: This paper studies why PhDs in France take longer to find stable jobs than engineers. Using data from CEREQ's "Génération 2004" survey, we show that job finding rates of PhDs are lower than those of engineers and document the differences in their observable characteristics and fields of study. We show that this phenomenon is due to multiple factors: heterogeneity in student characteristics along observable and unobservable dimensions and fields of study, directed search toward public sector positions (especially professors) among $\mathrm{PhDs}$ and, in all likelihood, reservation wages of $\mathrm{PhDs}$ for private sector jobs that are "too high" relative to their value of marginal product.

Mots Clés français: Insertion des jeunes, STEM, Recherche dirigée, subventions salairales, Dispositif jeunes docteurs, Crédit impôt recherche.

Mots clés anglais: School-to-work transition, STEM, Directed search, Wage subsidies.

JEL Codes / Codes JEL: J24, I23, J64

Appartenance Margolis: Paris School of Economics, CNRS et IZA. Address: 48 boulevard Jourdan, 75014 Paris, France. E-mail: David.N.Margolis@gmail.com.

Appartenance Miotti: CEPN Université Sorbonne Paris Nord et OST-HCERES. Address: 2, rue Albert Einstein, 75013 Paris. E-mail: egidio.miotti@ hceres.fr.

Remerciements en français: Les auteurs souhaitent remercier Frédérique Sachwald, deux rapporteurs anonymes, le comité de suivi interministerielle et les participants aux séminaires au Paris School of Economics, l'Université Paris Est-Créteil et aux Journées de Microéconomie Appliquée pour des remarques qui ont servi à améliorer ce texte. Cette recherche a bénéficié d'un financement du Ministère de l'éducation nationale, de l'enseignement supérieur et de la recherche dans le contexte de la préparation du rapport "Évaluation de l'impact du dispositif «jeunes docteurs » du crédit d'impôt recherche" et d'une subvention de l'Agence Nationale de la Recherche dans le cadre du programme "Investissements d'avenir", référence ANR-17-EURE-001.

Remerciements en anglais: The authors would like to thank Frédérique Sachwald, two anonymous 
referees, the comite de suivi interministerielle and participants of seminars at the Paris School of Economics, the Université Paris Est-Créteil and the Journées de Microéconomie Appliquée for helpful comments. This research was partially funded by the Ministère de l'éducation nationale, de l'enseignement supérieur et de la recherche in the context of preparation of the report "Évaluation de l'impact du dispositif « jeunes docteurs » du crédit d'impôt recherche" and partially by a French government subsidy managed by the Agence Nationale de la Recherche under the framework of the Investissements d'avenir programme, reference ANR-17-EURE-001. 


\section{Introduction}

France's higher education system faces a paradox. Students who graduate with $\mathrm{PhDs}$ take longer to find stable employment, defined as an indefinite-term contract or civil service position, than those who graduate with an engineering degree, despite having more years of schooling ( $\mathrm{PhDs}$ leave school at age 28.7 on average, engineers at age 23.9) and thus (in principle) more human capital ${ }^{1}$. This effect applies not only for $\mathrm{PhDs}$ as a whole, but also when restricting attention to $\mathrm{PhDs}$ who obtain their degrees in the same fields as engineers. Even more surprisingly, students who complement their engineering degree with a $\mathrm{PhD}$ still take longer to find stable employment than those who stop after obtaining their engineering degree and start looking for a job immediately. If human capital is increasing with education (Becker, 1993; Mincer, 1974), PhDs should be at least as productive, if not more productive, than engineers and thus more attractive to employers all else equal. So why do they take longer to get settled into the job market?

This paper examines several possible explanations for the paradox of a relatively slow transition of PhDs to stable employment. Using data from the Génération 2004 survey $^{2}$, we suggest and test several alternatives. First, we consider the "all else equal" hypothesis by focusing on differences among observable characteristics of graduates (grades, age, sex, region, parental background). We then examine the content of the human capital acquired by comparing the distribution of fields of study among engineers and PhDs. We follow that by exploring the theory of directed search (Wright et al., 2017), in which PhDs and engineers target different types of jobs. Next, we consider the possibility that $\mathrm{PhDs}$ have reservation wages that exceed their value of marginal product, and use the reform of a wage subsidy that targets PhDs to asses its importance. Finally, we look at the possibility that unobserved heterogeneity affects the speed of finding a stable job by controlling for the risk that education is endogenous with respect the rate of being hired for a stable job.

From a methodological point of view, we model the time until stable employment using semiparametric and parametric proportional hazard duration models. These models are particularly well adapted to this question because $38.4 \%$ of individuals in the sample have not found a stable job before the end of the sample window (between 3 and 5 years after school leaving), and the number grows to $93 \%$ when focusing only on private sector research and development (R \& D) positions, excluding professors. Duration models also allow us to separately consider the roles of observed and unobserved heterogeneity versus time dependence in determining the speed of

\footnotetext{
${ }^{1}$ See Margolis and Miotti (2015) for details.

${ }^{2}$ Génération 2004 is a survey run by the Center for Studies and Research on Qualifications (CEREQ) that samples individuals from the cohort of students who left school in 2004 without subsequently returning (Aliaga et al., 2010). Relative to the other Génération surveys, the 2004 cohort is unique in that it is the only one for which data was collected not only on the highest degree obtained, but also on degrees obtained prior to the highest degree, which allows us to identify students who followed up an engineering degree with a doctorate.
} 
job finding for the different types of graduates.

It is worth noting that this paper focuses only on the time to the first stable job and not other characteristics of the school-to-work transition. As such, it does not claim that a job search process that involves a series of unstable jobs that lead to a stable job (e.g. several post-doctoral or temporary teaching positions en route to a tenured teaching position) is inferior to a process by which a stable, but perhaps less appealing, job is found sooner. We also do not examine the earnings, career progression or working conditions of the jobs found, although we do consider whether the job is an R \& D position or not. We do not claim that any particular actor is behaving in an individually sub-optimal way, although the equilibrium outcome of having $\mathrm{PhDs}$ spend several years before settling into a stable job while engineers make the same transition more rapidly may be considered socially sub-optimal. In this sense, our analysis can be considered as providing insight into one component, albeit a particularly important component, of the school-to-work transition.

Our results suggest that each of the proposed explanations for the slower rate of transition to stable employment of $\mathrm{PhDs}$ relative to engineers finds some empirical support. Directed search, in particular a focus on $\mathrm{R} \& \mathrm{D}$ positions - especially professors - and the public sector, is a major contributor to the difference in overall stable job finding rates. We find support for "excessive" reservation wages as well, in that a sufficiently large wage subsidy appears to be able to induce employers to hire certain doctors more rapidly than comparable engineers. We also find that differences in the composition of the pool of engineers versus PhDs matters, along the lines of subjects studied and individual characteristics, both observable and unobservable.

The rest of this paper is organized as follows. The next section rapidly describes the differences in observable characteristics and fields between engineers and three different types of PhDs: PhDs who already have an engineering degree, $\mathrm{PhDs}$ without an engineering degree but who choose the same fields for doctoral study as those chosen by engineers who continue on to complete a $\mathrm{PhD}$, and $\mathrm{PhDs}$ in other fields. Section 3 presents the reference empirical specifications, while section 4 presents the results from these models. Section 5 examines the robustness of these specifications to focusing only on $\mathrm{R} \& \mathrm{D}$ positions (by classification and by activities) and allowing for education to be endogenous. Section 6 concludes by presenting the implications of these results for policies intended to accelerate the speed of transition of higher education graduates to stable employment.

\section{The School-to-Work Transitions of Engineers and PhDs in France}

The transition from school to a stable job differs dramatically between engineers and $\mathrm{PhDs}$ in France. This section begins by presenting several stylized facts related to differences in 
the school-to-work transition between $\mathrm{PhDs}$ and engineers based on an analysis of the data from the CEREQ's Génération 2004 survey, the data used throughout this paper ${ }^{3}$. It then briefly describes the key differences between the two populations and discusses the types of jobs targeted by PhDs and engineers in their job search. It ends by presenting a program that was designed to speed the transition to stable employment for PhDs that will be exploited in the empirical work ${ }^{4}$.

\subsection{Stylized Facts on the School-to-Work Transition of Engineers and PhDs}

Perhaps the most striking stylized fact concerning the school-to-work transition of engineers and $\mathrm{PhDs}$ is the difference in unemployment rates three years after leaving school. As shown in figure 1 , the unemployment rate three years after leaving school is only $3.5 \%$ for people who left school with a degree from an engineering school ${ }^{5}$, while $\mathrm{PhDs}$ have an unemployment rate of $8.6 \%$ three years after leaving school. Some people with engineer degrees continue on to complete a $\mathrm{PhD}$, and despite entering the labor market with additional human capital and (on average) 4.5 years older, their unemployment rate is nearly twice that of students who stop after obtaining their engineer degree. Nevertheless, having obtained an engineer degree before undertaking a $\mathrm{PhD}$ is associated with a lower unemployment rate, as these graduates have an unemployment rate that is roughly three-quarters of the unemployment rate of students with $\mathrm{PhDs}$ in the same field ${ }^{6}$ but without an engineering degree. Those who chose a different field for their PhD studies are the most likely to be unemployed after three years, with an unemployment rate nearly triple that of engineers.

Figure 1: Unemployment Rate of PhDs and Engineers in 2007, 3 Years After Leaving School

\section{insérer ici Figure 1}

Source: Génération 2004 and authors' calculations

In addition to having a lower unemployment rate, engineers transition to their first stable job sooner than doctors of all types. Figure 2 shows the distribution of time to the first stable job

\footnotetext{
${ }^{3}$ See appendix A for details on the data and the construction of the analysis data set.

${ }^{4}$ For a more detailed comparison of PhDs and engineers along all of these dimensions, see Margolis and Miotti (2015).

${ }^{5}$ France has a dual higher education system, with a university track and a "higher school" (grande école) track, distinguished primarily by the fact that entry into the university track is open to any student who successfully passed their baccalauréat (with one exception), while the "higher schools" can select students at entry. Among the "higher schools", several are considered engineering schools and deliver an engineering degree (diplôme d'ingénieur), although the fields covered can extend beyond standard fields such as mechanical engineering, electrical engineering, etc. into such fields as statistics or economics. The non-engineering fields are also typically available in the university track as well.

${ }^{6}$ An engineer field is defined as a field of doctoral study chosen by at least one student in our data who completed a $\mathrm{PhD}$ degree after having previously obtained an engineer degree. Note that this is an empirically-based definition using data from Génération 2004, not a definition based on an a priori classification of fields of study. See appendix B for a list of fields thus defined as "engineer fields" and those defined as "other fields".
} 
for engineers and all three types of PhDs among those who have found a stable job before their censoring date ${ }^{7}$. Engineers and $\mathrm{PhD}+$ Engineers find their stable jobs the fastest, but there is a notable mode in the distributions of time to first stable job for $\mathrm{PhD}$ - Engineer Field and $\mathrm{PhD}$ - Other Field graduates at 12 and 24 months. This suggests that these individuals may be accepting temporary positions, such as 1 or 2 year post docs, that delay the start of their first stable job.

Figure 2: Time to First Stable Job Among Uncensored Observations

insérer ici Figure 2

Source: Génération 2004 and authors' calculations

\subsection{The Characteristics of Engineers and PhDs}

Beyond their fields of study, engineers and PhDs differ along many important dimensions that can be related to the speed at which they find their first stable job. Table 1 presents the main characteristics of the sample of $\mathrm{PhDs}$ and engineers being studied; additional variables are presented in appendix table C.1. Clearly, engineers take less time to find their first stable job on average than $\mathrm{PhDs}$ since they are both less likely to be censored and have shorter average times to their first stable job when uncensored. In general, most of the characteristics that are over-represented among engineers are characteristics typically associated with shorter unemployment durations, although engineers tend to enter the labor market at a younger age than $\mathrm{PhDs}$, which tends to be associated with a lower probability of employment.

When comparing $\mathrm{PhDs}$ who specialize in a non-engineer field to engineers who left school immediately after completing their degree, we find several factors that could be linked to their slower insertion into the labor market. First, the PhDs are much more likely to be women than the engineers. Moreover, they are significantly less likely to have obtained their baccalauréat with honorable mention. By definition, they study different fields than those chosen by engineers who continue on to do a $\mathrm{PhD}$, and although some fields studied by these doctors are as successful in obtaining jobs as the specialties followed by engineers who continue to a $\mathrm{PhD}$, most of the fields have higher unemployment rates 3 years after leaving school (Margolis and Miotti, 2015). On the other hand, these $\mathrm{PhDs}$ are much more likely to have skipped a grade earlier in their schooling, and are more likely to have done a general baccalauréat (instead of a technical or professional baccalauréat), both factors associated with higher employability.

Considering $\mathrm{PhDs}$ in engineer fields who do not have an engineering degree, they also have characteristics that make them less likely to find stable jobs than engineers. As with $\mathrm{PhDs}$

\footnotetext{
${ }^{7}$ All individuals were either censored 3 or 5 years after leaving school, depending on whether on not they completed the "full questionnaire" in 2007 and the ability of the CEREQ to locate them. The share of individuals that found a stable job before the end of the sample window, by degree, was $86.5 \%$ for engineers, $65.7 \%$ for $\mathrm{PhD}+$ Engineers, $48.8 \%$ for $\mathrm{PhD}$ - Engineer Field and $45.3 \%$ for $\mathrm{PhD}$ - Other Field.
} 
Table 1: Descriptive Statistics for Key Variables, Means with Std. Deviations in Parentheses

\begin{tabular}{|c|c|c|c|c|c|}
\hline & $\begin{array}{c}\text { Overall } \\
\text { Mean }\end{array}$ & Engineers & $\begin{array}{c}\mathrm{PhD}+ \\
\text { Engineer } \\
\end{array}$ & $\begin{array}{c}\mathrm{PhD} \text { - } \\
\text { Engineer Field } \\
\end{array}$ & $\begin{array}{c}\text { PhD - } \\
\text { Other Field }\end{array}$ \\
\hline $\begin{array}{l}\text { Time to First Stable Job } \\
\text { If Uncensored }\end{array}$ & $\begin{array}{c}12.767 \\
(10.9008)\end{array}$ & $\begin{array}{c}11.273 \\
(9.6476)\end{array}$ & $\begin{array}{c}20.284 \\
(14.1164)\end{array}$ & $\begin{array}{c}16.832 \\
(13.3132)\end{array}$ & $\begin{array}{l}13.914 \\
(7.8524)\end{array}$ \\
\hline $\begin{array}{l}\text { Time to First Stable Job } \\
\text { or Censoring }\end{array}$ & $\begin{array}{c}24.323 \\
(20.9855)\end{array}$ & $\begin{array}{c}16.402 \\
(16.5471)\end{array}$ & $\begin{array}{c}26.192 \\
(16.9506)\end{array}$ & $\begin{array}{c}37.426 \\
(22.0023)\end{array}$ & $\begin{array}{c}28.420 \\
(17.1554)\end{array}$ \\
\hline Percentage Uncensored & 0.701 & 0.871 & 0.734 & 0.439 & 0.471 \\
\hline Age at School Leaving & $\begin{array}{l}25.793 \\
(2.9413)\end{array}$ & $\begin{array}{c}23.872 \\
(1.1856)\end{array}$ & $\begin{array}{l}28.116 \\
(1.7668)\end{array}$ & $\begin{array}{l}28.468 \\
(2.4413)\end{array}$ & $\begin{array}{l}29.744 \\
(2.1775)\end{array}$ \\
\hline Male & 0.645 & 0.768 & 0.722 & 0.443 & 0.467 \\
\hline Born in France & 0.954 & 0.965 & 0.974 & 0.930 & 0.959 \\
\hline Skipped a Grade Before 6th Grade & 0.110 & 0.096 & 0.093 & 0.130 & 0.159 \\
\hline Repeated a Grade Before 6th Grade & 0.012 & 0.010 & 0.012 & 0.015 & 0.019 \\
\hline Did Not Attend 6th Grade & 0.003 & 0.003 & 0.002 & 0.001 & 0.009 \\
\hline Baccalauréat Other Than General & 0.106 & 0.128 & 0.029 & 0.079 & 0.068 \\
\hline Baccalauréat with Honorable Mention & 0.352 & 0.347 & 0.350 & 0.372 & 0.298 \\
\hline Baccalauréat with Honors & 0.201 & 0.207 & 0.333 & 0.183 & 0.179 \\
\hline Baccalauréat with High Honors & 0.051 & 0.054 & 0.153 & 0.035 & 0.057 \\
\hline \multicolumn{6}{|l|}{ Fields of Study } \\
\hline Life Sciences & 0.025 & 0.002 & 0.046 & 0.070 & \\
\hline Chemistry & 0.025 & 0.017 & 0.110 & 0.038 & \\
\hline Physics & 0.038 & 0.035 & 0.211 & 0.039 & \\
\hline Health & 0.230 & 0.020 & 0.107 & 0.672 & \\
\hline Economics & 0.011 & 0.002 & 0.008 & 0.031 & \\
\hline General and Precision Mechanics & 0.030 & 0.050 & 0.018 & 0.000 & \\
\hline Fundamental Industrial Technologies & 0.114 & 0.185 & 0.032 & 0.009 & \\
\hline Electricity and Electronics & 0.063 & 0.099 & 0.038 & 0.007 & \\
\hline Computer Science & 0.075 & 0.109 & 0.095 & 0.024 & \\
\hline Earth Sciences & 0.011 & 0.008 & 0.042 & 0.016 & \\
\hline Other Engineer Fields & 0.196 & 0.266 & 0.293 & 0.095 & \\
\hline Number of Observations & 2,526 & 920 & 184 & 1,052 & 370 \\
\hline
\end{tabular}

Source: Génération 2004 and authors' calculations. 
from other fields, they are significantly less likely to be male. They are also less likely to have been born in France and they are significantly less likely to have obtained their baccalauréat with high honors. They are also significantly more likely to specialize in fields that have been found to have difficulty finding jobs, such as chemistry, life sciences and economics, and less likely to choose fields that find jobs easily, such as electricity and electronics, computer science and other engineering fields. However, like other PhDs, they also have certain characteristics associated with faster job finding, such as being more likely to have skipped a grade before sixth grade and being more likely to have done a general baccalauréat.

The main differences between engineers who pursue their studies with a $\mathrm{PhD}$ and other engineers relate to their performance on the baccalauréat exam and their choices of field of study. The engineers who continue their studies with a $\mathrm{PhD}$ were significantly more likely to have obtained their baccalauréat with honors or high honors than engineers who did not, suggesting that these students were the most successful of all graduates in our sample at the time they passed their baccalauréat. However, they are also much more likely to have specialized in lesspromising fields such as chemistry, life sciences and physics, and less likely to choose fields that find jobs easily, such as electricity and electronics and fundamental industrial technologies.

\subsection{The Types of Jobs Targeted by PhDs and Engineers}

Another possible explanation for the slower transition to stable jobs by PhDs relative to engineers could be that they engage in directed search. If engineers are open to a wide range of positions in the private or public sector while PhDs initially target positions for which the supply is particularly limited, or only target permanent positions after a series of fixed-term positions such as post-docs or temporary teaching posts, one would expect $\mathrm{PhDs}$ to take longer to find stable jobs than engineers.

Table 2 describes the career plans that PhDs held at the time of their defense ${ }^{8}$. Overall, nearly three quarters of $\mathrm{PhDs}$ wanted to work in the public sector, almost exclusively in research. However, only $52 \%$ of $\mathrm{PhD}+$ engineers were targeting public sector research positions (which includes professors), while $69 \%$ of $\mathrm{PhD}$ - engineer field students and $87 \%$ of $\mathrm{PhD}$ - other field students were targeting those jobs. Moreover, when $\mathrm{PhD}$ - other field students plan on careers in the private sector, they do not target $\mathrm{R} \& \mathrm{D}$ positions, whereas other types of $\mathrm{PhDs}$ still aim for research positions, albeit with a weaker preference for research than among those looking for public sector positions. These career plans may be reflecting a "taste for science" among $\mathrm{PhDs}$ in line with the results of Roach and Sauermann (2010), who have shown that PhDs who look for private sector positions have a weaker "taste for science" and a stronger preference for the development side of research and development, relative to those who target an academic

\footnotetext{
${ }^{8}$ Information on career plans of engineers is not available in the Génération 2004 survey.
} 
career. These $\mathrm{PhDs}$ who targeted the private sector were also shown to be more attentive to questions of earnings and access to resources more generally.

Table 2: Career Plans of PhDs at the Time of Defense, in \%

\begin{tabular}{|c|c|c|c|c|}
\hline & $\begin{array}{c}\mathrm{PhD}+ \\
\text { engineer }\end{array}$ & $\begin{array}{c}\mathrm{PhD} \text { - } \\
\text { engineer field }\end{array}$ & $\begin{array}{c}\text { PhD - } \\
\text { other field }\end{array}$ & Total \\
\hline Public Sector & $\overline{533,73}$ & 71,68 & 88,87 & $\mathbf{7 4 , 7 0}$ \\
\hline \multicolumn{5}{|l|}{ of which } \\
\hline Public research & 52,50 & 69,09 & 87,01 & 72,79 \\
\hline Teacher & 0,66 & 1,95 & 0,53 & 1,31 \\
\hline Other civil servant & 0,57 & 0,64 & 0,53 & 0,60 \\
\hline Private Sector & 43,08 & 24,98 & 9,36 & 22,24 \\
\hline \multicolumn{5}{|l|}{ of which } \\
\hline Research in a company & 34,97 & 16,26 & 2,01 & 14,05 \\
\hline Other private sector employment & 8,11 & 8,72 & 7,35 & 8,19 \\
\hline Work in research & 0,33 & 0,48 & 0,13 & 0,35 \\
\hline Other & 0,33 & 1,77 & 1,98 & 1,65 \\
\hline Do not know, No preference & 2,54 & 1,07 & 0,46 & 1,06 \\
\hline
\end{tabular}

Source: Génération 2004

Despite having initially targeted public sector research positions, most $\mathrm{PhDs}$ (and the vast majority of engineers) find themselves employed in the private sector three years after leaving school. Table 3 shows the distribution of jobs held by engineers and $\mathrm{PhDs}$ three years after obtaining their degree. Over $90 \%$ of engineers are employed in the private sector, while $\mathrm{PhD}+$ engineer and $\mathrm{PhD}$ - engineer field graduates are split roughly half-and-half between the public and private sectors. On the other hand, only $27 \%$ of $\mathrm{PhD}$ - other field graduates are employed in the private sector. Moreover, this is the category of $\mathrm{PhD}$ for whom the actual placement differs the most from their career plan upon obtaining their degree ${ }^{9}$.

The fact that PhDs find themselves in jobs that differ significantly from those that they originally targeted suggests that the career plans were revised during the three years between degree receipt and the survey administration and that PhDs may be particularly prone to "structural career accidents" (Margolis and Yassin, 2017). Such a result would be consistent with directed search in a narrow area (public sector research positions) in the period soon after obtaining a degree, with the set of acceptable jobs being broadened as time goes by. Since public sector research positions are rare relative to private sector jobs, even a reservation wage equal to the minimum wage might not be sufficient to find an acceptable job offer, as the offer arrival rate is likely to be very low. By broadening the set of acceptable offers, the offer arrival rate increases

\footnotetext{
${ }^{9}$ Given that the career plans are measured three years after the defense, it is possible that the responses to the career plan questions in the Génération 2004 survey suffer from bias due to ex-post rationalization. If this were to be the case, then the differences reported here would underestimate the true gap between career plans at graduation and actual career outcomes.
} 
and the probably of finding a job can increase as well, provided that the reservation wage does not increase too much as a result of looking for a job among a broader set of potential employers with a potentially different offered wage distribution.

Table 3: Jobs Held Three Years After Degree Receipt by Type of Employer, in \%

\begin{tabular}{|c|c|c|c|c|c|}
\hline & Engineers & $\begin{array}{c}\mathrm{PhD}+ \\
\text { Engineers }\end{array}$ & $\begin{array}{c}\text { PhD - } \\
\text { Engineer } \\
\text { Field }\end{array}$ & $\begin{array}{l}\text { PhD - } \\
\text { Other } \\
\text { Field }\end{array}$ & Total \\
\hline Public Sector & $\overline{7,33}$ & $\overline{49,76}$ & $4 \mathbf{4 6 , 5 0}$ & 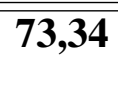 & 24,93 \\
\hline Professors and Teachers & 3,17 & 34,09 & 24,38 & 62,51 & 14,84 \\
\hline Other Central Government & 1,95 & 10,15 & 7,58 & 6,14 & 4,13 \\
\hline Local Government & 1,36 & 0,54 & 1,22 & 3,28 & 1,45 \\
\hline Hospitals & 0,10 & 3,26 & 12,06 & 0,48 & 3,57 \\
\hline Other Public Sector & 0,75 & 1,72 & 1,26 & 0,93 & 0,94 \\
\hline State-Owned Enterprises & $\mathbf{1 , 8 1}$ & $\mathbf{0 , 7 3}$ & $\mathbf{0 , 5 1}$ & $\mathbf{0 , 0 0}$ & 1,27 \\
\hline Private Sector & 90,85 & 49,50 & 52,99 & 26,66 & $\mathbf{7 3 , 8 0}$ \\
\hline
\end{tabular}

Source: Génération 2004 and authors' calculations

\subsection{The "Young Doctors Program" (Dispositif Jeunes Docteurs) of the Research Tax Credit (Crédit Impôt Recherche)}

In 1999, the French government introduced the "Young Doctors Program" (DJD) of the Research Tax Credit (CIR) in an attempt to reduce the cost to private sector firms of hiring PhDs. This program has been made increasing generous over time, although its usage was still rather limited during the period under investigation in this paper (2004-2009) ${ }^{10}$. Such a reform could be an appropriate policy response to the relatively slow transition of $\mathrm{PhDs}$ into stable jobs if part of the reason was that reservation wages were "too high" relative to the value of marginal product of $\mathrm{PhDs}$ in the private sector. This could occur, for example, if $\mathrm{PhDs}$ overestimate the offered wage distribution in the private sector or if they require a compensating differential in order to accept a private sector job over one in the public sector. If the tax reduction due to the wage subsidy provided by the DJD program was larger than the cost increase associated with offering a higher wage (large high enough to incite PhDs to accept the job) and the conditions for obtaining the subsidy were not too onerous ${ }^{11}$, employers would take advantage of the program and $\mathrm{PhDs}$ would access private sector jobs faster ${ }^{12}$. Giraud et al. (2014) provides

\footnotetext{
${ }^{10}$ See Margolis and Miotti (2015) for details on take-up of the DJD program by employers.

${ }^{11}$ One of the conditions for obtaining the subsidy was that employers could not benefit from the subsidy if they reduced employment in the same year (see Giraud et al. (2014)). This condition is likely linked to the concentration of DJD beneficiaries among smaller firms, especially those in the 10-249 employee range (Margolis and Miotti, 2015).

${ }^{12}$ In their study of the impacts of the DJD, Bernela et al. (2017) find $12.4 \%$ larger monthly earnings for PhDs relative to engineers in private sector $\mathrm{R} \& \mathrm{D}$ positions (table 5), a result consistent with the hypothesis that the
} 
a detailed description of the CIR and its changes over time; below we briefly present the main reforms that occurred during our sample window and how they have successively reduced the cost of hiring a $\mathrm{PhD}$ relative to an engineer.

\subsubsection{The Origins of the DJD (Law of July 12, 1999 on Innovation and Research) and the Situation on January 1, 2004}

Article 8 of the Law on Innovation and Research introduced the DJD into the CIR. This program allowed firms to include $100 \%$ of declared operating expenses associated with the hiring of $\mathrm{PhDs}$ as operating expenses for the purposes of calculating their research tax credit $^{13}$, provided that the $\mathrm{PhDs}$ were hired on indefinite term contracts and that total employment in the firm was not lower than the previous year. This change meant that, for a given compensation cost and a given hiring expenditure, it became effectively less costly for a firm to hire a $\mathrm{PhD}$ instead of an engineer for a researcher or research technician position.

\subsubsection{The DJD in the 2006 Reform}

Article 22 of the 2006 budget reformed the DJD by allowing firms to account for the compensation cost of a recently hired $\mathrm{PhD}$ at $200 \%$ of its actual cost for the first twelve months of the indefinite term contract, provided it was the PhD's first indefinite term contract and that total employment in the firm was not lower than the previous year. Moreover, firms could include $200 \%$ of operating expenses associated with the hiring of PhDs, instead of the previous $100 \%$. The conditionality for the hiring cost deduction was left unchanged. This reform further reduced the cost of hiring $\mathrm{PhDs}$, as both the operating cost and direct compensation cost dimensions of the tax credit calculation were increased only for PhDs, not for engineers, in research positions.

\subsubsection{The DJD in the 2008 Reform}

Article 69 of the 2008 budget reformed both the CIR and the DJD. This reform extended the pre-existing DJD conditions to 24 months, both for the direct accounting of compensation cost and for the inclusion of hiring costs in operating expenses, without changing the conditionality. Moreover, the general reforms to the CIR, in particular the removal of the cap on the amount of the credit that could be claimed and shift from calculating the credit primarily based on changes in research spending to calculating the credit primarily based on levels of research spending, transformed the 2008 DJD reform into a massive subsidy for hiring research personnel (Bozio et al., 2014) and further increased the potential impact of these reforms in terms cost reductions for firms that hired $\mathrm{PhDs}$.

DJD allows employers to offer higher earnings and thus attract workers with higher reservation wages.

${ }^{13}$ Operating expenses associated with research-related hiring for non-PhD personnel were included in at a fixed rate of $75 \%$ of their declared amount. 


\section{Econometric Specification}

In order to understand the determinants of the speed at which $\mathrm{PhDs}$ and engineers find stable jobs, we use proportional hazard duration models (Lancaster, 1990). This approach, which involves estimating the determinants of the rate of exit from a spell (in this case the time between obtaining one's degree and finding one's first stable job ${ }^{14}$ ) is particularly well adapted to modeling the school-to-work transition for three reasons. First, the length of the spell is positive-valued and stochastic, even conditional on observables. Second, the length of the spell can be affected by observable and unobservable characteristics, but can also exhibit time dependence for reasons other than changes in composition of the risk pool. Third, spells can be right-censored, meaning that (in this case) one does not observe the time at which the person finds his or her first stable job, only a time strictly less than that date (typically when the sample window ends ${ }^{15}$ ).

Concretely, we estimate a series of proportional hazards duration models, each of which is designed to allow us to examine empirically the various possible explanations for the difference in the speed of finding a stable job. The contribution to the likelihood function for an individual $i$ with observable time-invariant characteristics $X_{i}$ for which the time $t_{i}$ is observed, where $t_{i}$ is the time to the first stable job when an indicator $d_{i}=1$ and $t_{i}$ is the time to right censoring when $d_{i}=0$, can be written as:

$$
L\left(t_{i} \mid d_{i}, X_{i}\right)=h\left(t_{i} \mid X_{i}\right)^{d_{i}} \exp \left(-\int_{0}^{t_{i}} h\left(s \mid X_{i}\right) d s\right)
$$

with $h\left(t_{i} \mid X_{i}\right)$ being the hazard function and $\exp \left(-\int_{0}^{t_{i}} h\left(s \mid X_{i}\right) d s\right)$ being the survivor function. The hazard function $h\left(t_{i} \mid X_{i}\right)$ takes the standard proportional hazards form, with

$$
h\left(t_{i} \mid X_{i}\right)=g\left(X_{i}\right) h_{0}\left(t_{i}\right)
$$

with $g\left(X_{i}\right)=\exp \left(X_{i} \beta\right)$ being the proportionality factor and $h_{0}\left(t_{i}\right)$ being the baseline hazard. In our parametric specifications, we adopt a flexible functional form for the baseline hazard (a

\footnotetext{
${ }^{14}$ We also consider a second type of spell, the time between obtaining one's degree and finding one's first indefinite term contract in the private sector.

${ }^{15}$ Models that restrict attention to a subset of stable jobs, such as private sector stable jobs or R \& D positions, estimate the models using a competing risks framework in which the censoring time can either be the end of the sample window or the time at which the individual makes a transition to another type of stable job. This occurs, for example, when examining the time to the first stable private sector job and an individual finds a public sector position (which has a guarantee of lifetime employment) first.
} 
piecewise constant model) for which the functional form can be written as

$$
\begin{aligned}
h_{0}(t)= & \theta_{1} \text { if } \tau_{0}<t \leq \tau_{1} \\
& \theta_{2} \text { if } \tau_{1}<t \leq \tau_{2} \\
& \vdots \\
& \theta_{k+1} \text { if } t>\tau_{k} .
\end{aligned}
$$

with $\tau_{0}=0$.

The models are built sequentially, starting with a baseline specification that allows us to begin examining the "all else equal" hypothesis by conditioning on observable characteristics. These baseline specifications also allow us to understand the importance of directed search away from private sector positions, as well as confirming the flexibility of our parametric specification relative to a semi-parametric alternative ${ }^{16}$. We then consider the hypothesis of inappropriate reservation wages by introducing a set of time-varying covariates ${ }^{17}$ for the various reforms of the $\mathrm{DJD}$, which should affect private sector research personnel as a whole and $\mathrm{PhDs}$ in particular. A disproportionate increase in hiring of $\mathrm{PhDs}$, relative to engineers, after the incentives of the DJD program become more generous can be interpreted as consistent with the inappropriate reservation wage hypothesis. We next consider the role of unobserved heterogeneity ${ }^{18}$, in case there are unobserved factors that affect the speed of transition other than observable characteristics and compensation cost. Beyond correcting the baseline hazard for composition bias due to the unobserved heterogeneity, controlling for unobserved heterogeneity would be important, for example, in the unlikely event that individuals delay their school leaving in order to take advantage of future reforms, which would increase the chances of being eligible for the DJD reforms and thus make the DJD-related covariates endogenous ${ }^{19}$. Finally, we explore the robustness of these results in two directions, first by considering a narrower definition of directed search (R \& D positions with or without professorships) and second by allowing for education to be endogenous with respect to the job finding process ${ }^{20}$.

Since the estimation of a proportional hazards model with unobserved heterogeneity using the Heckman and Singer (1984b) technique requires the specification of a parametric baseline

\footnotetext{
${ }^{16}$ See Cox (1972) for a presentation of the semi-parametric models used here. The estimated models explicitly account for the interval-observed nature of the Génération 2004 data, since spell lengths in the data are measured in months and not in continuous time.

${ }^{17}$ Time-varying covariates are incorporated into equation (1) by breaking the spell into pieces during which the covariates remain constant, and treating each sub-spell as right censored and/or stock sampled as needed. See Lancaster (1990) for details.

${ }^{18}$ Unobserved heterogeneity is modeled using the random-effects approach proposed in Heckman and Singer (1984b).

${ }^{19}$ Despite the fact that the CIR was being reformed on an annual basis, the 2006 and 2008 DJD reforms were not pre-announced in 2004 and thus such anticipatory behavior seems unlikely.

${ }^{20}$ Endogenous education is modeled by adapting the instrumental variables for duration models technique proposed by Bijwaard (2009).
} 
hazard $^{21}$, we suppose a flexible parametric model using a piecewise constant baseline hazard function as described in equations (2) and (3) in addition to a semi-parametric specification. To implement the piecewise constant model, we must choose the time intervals over which we assume the hazard rate into stable jobs to be constant (conditional on observables and unobservables). This choice must allow for enough flexibility to capture the time path of observed exits, yet not specify intervals so narrowly that too few exits are observed in any given interval to identify the associated parameter. After observing the unconditional distribution of exits to stable jobs ${ }^{22}$, we chose to specify the following intervals for the piecewise constant baseline hazard (in months): (0-12], (12-15], (15-18], (18-21], (21-24], (24-27], (27-30], (30-33], (33-36], (36-41], (41- $\infty)$.

The proportionality factor in the proportional hazards specification includes a number of observable characteristics that reflect an individual's family environment, the local context when leaving school, characteristics of his or her educational history and other demographic characteristics. In particular, our specifications include the following variables: highest degree obtained $^{23}$, gender, whether or not the person was born in France, whether or not the person skipped a grade before sixth grade, whether or not the person repeated a grade before sixth grade, whether or not the person ever attended sixth grade, if the person obtained their baccalauréat with honorable mention (assez bien), honors (bien) or high honors (très bien or félicitations du jury), the field of study (12 different fields), the region in which the institution that delivered the highest degree obtained was situated (22 regions), the occupation of the father at the time of graduation ( 7 categories) and the occupation of the mother at the time of graduation (7 categories). Descriptive statistics can be found in tables 1 and C.1.

\section{Main Results}

This section presents the results from estimating the main models described in section 3 . We begin by presenting the baseline specifications that condition on observable characteristics. These baseline specifications allow us to examine directly the differences in the speed of finding a stable job for PhDs versus engineers and allow us to explore the role of the parametric assumptions for the baseline hazard and impact of engaging in job search that prefers public sector to private sector jobs. We then explore the additional effect that reducing the relative

\footnotetext{
${ }^{21}$ Heckman and Singer (1984b, p. 300) note that although one can establish the integrability of the likelihood in the general case, "To produce explicit formulae requires adopting a parametric specification for $z(t)$ and $\zeta(x)$ ". ${ }^{22}$ Unlike much of the literature, we were forced to adopt a long interval for the first piece of the baseline hazard due to a very limited number of observed exits during the first year after school leaving, in particular for transitions to private sector R \& D positions. Even with this grouping, we still only observe 4 exits for PhD other field and 9 exits for PhD + Engineer graduates in the first 12 months. This implies that much of the identification of this piece of the baseline hazard for the model of transitions to private sector R \& D positions is driven by engineers.

${ }^{23}$ We examine only $\mathrm{PhDs}$ and engineers, and separately consider individuals with a $\mathrm{PhD}$ and an engineering degree, those with a PhD and no engineering degree who have studied a field in which $\mathrm{PhD}+$ engineers have studied, and $\mathrm{PhDs}$ without engineering degrees who have studied other fields.
} 
cost of employing PhDs has on the speed of transition into stable jobs by introducing the timevarying covariates associated with the DJD reforms. Finally, we observe how the estimates change with the introduction of unobserved heterogeneity.

\subsection{Baseline Models}

Columns 1 and 2 of table 4 present the main results from estimating our model of the instantaneous rate of finding one's first stable job, provided that the first stable job had not yet been found (the hazard rate). Recall that a positive coefficient in the proportionality factor of the hazard rate implies a faster transition to a stable job and thus a shorter time between school leaving and the start of the first stable job. Comparing columns 1 and 2 shows that the piecewise constant assumption does not appear to significantly affect the estimated coefficients on observables relative to the semi-parametric (Cox) alternative. 
Table 4: Effect of Education on Hazard Rate to a Stable Job, Without Unobserved Heterogeneity

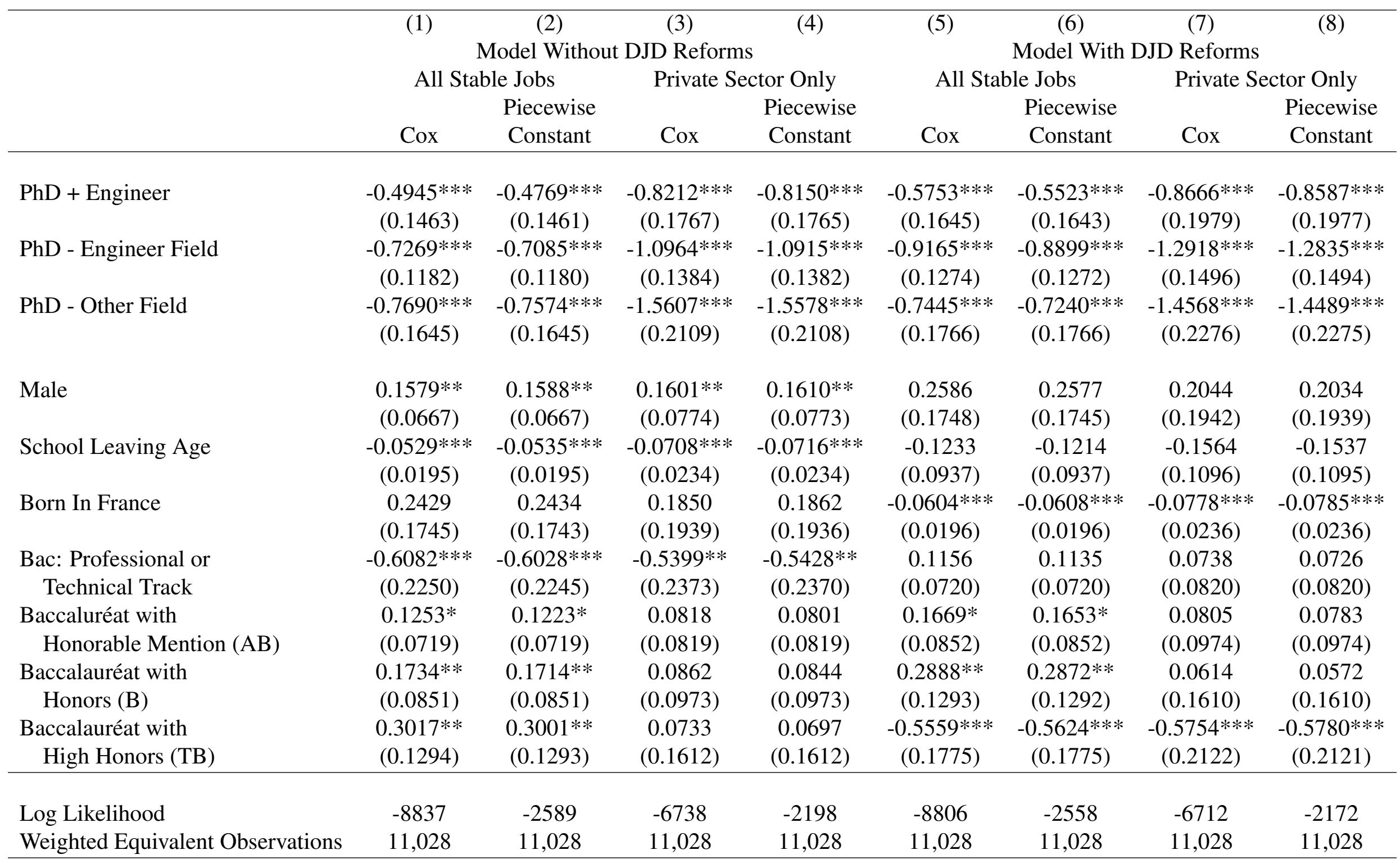

Standard Errors in Parentheses. Models also include controls for foreign born, having skipped a grade before 6th grade, having repeated a grade before sixth grade, not having attended sixth grade, field of studies (12 categories), region of the higher education institution (22 regions), father's occupation (7 categories) and mother's occupation (7 categories). The reference person has an engineering degree, is female, did general track studies for the baccalauréat, and obtained the baccalauréat with no mention or honors. $* * * \mathrm{p}<0.01, * * \mathrm{p}<0.05, * \mathrm{p}<0.1$ 
The results in table 4 show that, all else (observable) equal and before accounting for the effects of the DJD reforms, engineers (the reference category) find stable jobs significantly faster than all types of PhDs. Given that this effect persists even after controlling for broad range of observables, it may be due in part to the fact that graduates from some engineering schools in France are guaranteed civil service positions upon graduation, which shortens the time to finding a stable job as no extra job search is required. In particular, even after controlling for the field of study, school leaving age and performance on the baccalauréat exam, $\mathrm{PhD}+$ engineers still find stable jobs significantly slower than engineers. There also appears to be an engineering degree effect when comparing $\mathrm{PhDs}$ in engineer fields who have an engineering degree to those who do not; the former find their first stable job significantly faster ( $\mathrm{P}$-value $=0.0560$ in the Cox specification) than the latter. The field of study does not appear to have a significant effect on the speed of finding a stable job when one includes the public sector, as the hazard rates of $\mathrm{PhD}$ - engineer field and $\mathrm{PhD}$ - other field graduates are not significantly different from each other $(\mathrm{P}-\mathrm{value}=0.7879)$.

A comparison of columns 1 and 2 of table 4 with columns 3 and 4 shows that our results are consistent with the sort of directed search expressed by PhDs in the Génération 2004 data and shown in table $2^{24}$. The first point to note is that all of the coefficients on $\mathrm{PhD}$ categories become significantly more negative when restricting attention to transitions into private sector stable jobs only. This means that whereas the overall stable job hazard rate for a $\mathrm{PhD}$ with an engineering degree $\mathrm{PhDs}$ might be $61 \%$ of a comparable engineer's hazard rate ${ }^{25}$, the private sector stable job hazard rate for $\mathrm{PhD}+$ engineers is only $44 \%$ that of engineers ${ }^{26}$. Moreover, the field of study becomes more important when focusing on private sector jobs, as the difference between $\mathrm{PhD}$ - engineer field and $\mathrm{PhD}$ - other field graduates becomes significant ( $\mathrm{P}$-value= 0.0208). This suggests that $\mathrm{PhDs}$ who study fields other than those chosen by engineers are at a disadvantage when looking for private sector jobs, but that this disadvantage is counterbalanced by a relatively higher likelihood of finding a stable job in the public sector so that overall there is no significant difference among $\mathrm{PhDs}$ without engineer degrees when pooling public and private sector jobs.

\footnotetext{
${ }^{24}$ Although these results are compatible with directed search, discrimination against PhDs by private sector employers and a relatively limited supply of public sector positions could also generate similar results. Unfortunately, it is impossible with our data to identify employer discrimination. Concerning hiring by the public sector, the period covered by our data (2004-2008) saw a relatively high level of new hires by the Ministry of Higher Education and Research. According to the French government (https://www.fonction-publique.gouv.fr/serieslongues-0), the period covered by our data averaged 29756 new hires per year, while the most recent 5 -year period available, covering the period 2011-2015, shows an average new hiring rate of 22702 per year.

${ }^{25} \exp (-0.4945)=0.6099$.

${ }^{26} \exp (-08212)=0.4399$.
} 


\subsection{Baseline Models, Controlling for DJD Reforms}

Introducing time-varying covariates to the baseline specification to account for exogenous variation in the relative cost of hiring PhDs (as implied by the successive reforms to the DJD) has an important effect on the hazard rates of PhDs relative to engineers, as would be expected if $\mathrm{PhDs}$ had reservation wages that were "too high" relative to the value of their marginal product in the private sector. Note that since the DJD reforms are introduced as time varying covariates, the figures in columns 5-8 of table 4 reflect hazard rates prior to the 2006 reform. Hazard rates after the 2006 reform and before the 2008 reform are found by combining the results in table 4 with those in table 5.

Although the subsidy associated with the 2008 reform was massive, it should be noted that these coefficients are not presented ${ }^{27}$ due to instability arising from a lack of data. Indeed, only 170 of the 2030 (unweighted) spells in the data continued past $2008^{28}: 53$ for engineers, 3 for $\mathrm{PhD}+$ engineers, 102 for $\mathrm{PhD}$ - engineer field and 12 for PhD - other field. Moreover, only 11 of these spells actually ended with the individual finding a stable job, and no individuals with a $\mathrm{PhD}$ - other field were observed to have found a stable job after 2008 , so the coefficient is not identified (and therefore suppressed in the model).

Table 5: Effect of DJD Reforms on Hazard Rate to a Stable Job, Without Unobserved Heterogeneity

\begin{tabular}{ccccc}
\hline & $(5)$ & $(6)$ & $(7)$ & $(8)$ \\
& \multicolumn{2}{c}{ All Stable Jobs } & Private & Sector Only \\
& Cox & Constant & Cox & Piecewise \\
& Constant \\
\hline & & & & \\
Post 2006 Reform * & 0.2324 & 0.2110 & 0.0710 & 0.0626 \\
PhD + Engineer & $(0.2463)$ & $(0.2462)$ & $(0.3138)$ & $(0.3137)$ \\
Post 2006 Reform * & $0.5514 * * *$ & $0.5279 * * *$ & $0.5528 * * *$ & $0.5448 * * *$ \\
PhD - Engineer Field & $(0.1414)$ & $(0.1412)$ & $(0.1615)$ & $(0.1613)$ \\
Post 2006 Reform * & -0.0341 & -0.0575 & -0.3198 & -0.3293 \\
PhD - Other Field & $(0.2216)$ & $(0.2215)$ & $(0.3493)$ & $(0.3492)$ \\
\hline
\end{tabular}

Notes: Models contain the same control variables as in table 4, as well as controls for whether the spell ended after the 2006 reform, after the 2008 reform, and interactions of the Post 2008 reform indicator with the education indicators. The reference group is narrowed to include only the period from January 12004 to December 312005 for the reference person.

$* * * \mathrm{p}<0.01, * * \mathrm{p}<0.05, * \mathrm{p}<0.1$

\footnotetext{
${ }^{27}$ The model estimated does control for the spells that last beyond 2008 and a post-2008 indicator interacted with the various levels of education in order to ensure that the Post-2006 coefficients only capture the effects of the 2006 reform and not a combination effects of the 2006 and 2008 reforms.

${ }^{28}$ This is not an issue for the 2006 reform, as 980 spells ended after the 2006 reform and before the 2008 reform, and 38.78 percent of those spells ended with the person finding a stable job.
} 
Table 5 shows that the hiring of $\mathrm{PhDs}$ is indeed sensitive to their compensation $\operatorname{cost}^{29}$. Although engineers still have a significantly higher hazard rate than all forms of $\mathrm{PhDs}$ prior to the reforms in 2006, and despite the fact that the coefficients for all types of $\mathrm{PhD}$ do not significantly change, the difference between $\mathrm{PhD}$ - engineer field and $\mathrm{PhD}$ - other field graduates when looking for private sector jobs disappears ( $\mathrm{P}$-value $=0.3180$ in the Cox specification), suggesting that the DJD advantage of $\mathrm{PhD}$ - engineer field graduates seen in table 4 stems from the postreform periods.

When looking directly at the effects of the reforms (table 5), it becomes clear that the subsidy associated with the 2006 reform had significant effects for $\mathrm{PhD}$ - engineer field graduates. Using the piecewise constant results for $\mathrm{PhD}$ - engineer field graduates as an example, the hazard rate into stable jobs was 0.4107 times that of engineers ${ }^{30}$ prior to 2006 whereas it had increased to 0.6963 times that of engineers between 2006 and $2008^{31}$. This result is consistent with the possibility that $\mathrm{PhDs}$ have a reservation wage that exceeds their value of marginal product, and that the subsidy allows employers to propose wages that are sufficient to attract $\mathrm{PhDs}$ in engineer fields. That said, it is also possible that part of the positive effect for $\mathrm{PhDs}$ in engineer fields after the 2006 reform of the DJD can be explained by changes in the composition of graduates who are still without a stable job after 2006 in the dimension of unobservables. We address this possibility in section 4.3 below, and consider the possibility that the final degrees obtained may be endogenous with respect to the time it takes to find a job in section 5.2 .

\subsection{Models Controlling for DJD Reforms and Unobserved Heterogene- ity}

The baseline models presented thus far do not control for unobserved heterogeneity, and thus changes in the composition of the pool of individuals who have yet to find a stable job along the dimension of unobserved characteristics can bias the estimators of time varying covariates, such as the DJD reform indicators, and the baseline hazard. We therefore adopt the approach of Heckman and Singer (1984b) to introducing unobserved heterogeneity and rewrite the contributions to the likelihood function described in equation (1) as

$$
L\left(t_{i} \mid d_{i}, X_{i}\right)=\sum_{m=1}^{M} P\left(\nu=\nu_{m}\right) h\left(t_{i} \mid X_{i}, \nu_{m}\right)^{d_{i}} \exp \left(-\int_{0}^{t_{i}} h\left(s \mid X_{i}, \nu_{m}\right) d s\right) .
$$

\footnotetext{
${ }^{29}$ Recall that the effect of the reforms is identified, despite having occurred at the same calendar dates for all individuals in the sample, by the fact that time is measured in the model relative to the school leaving date. People who leave school in different months of 2004 will thus experience the reforms at different lengths of time into their job search process.

${ }^{30} \exp (-0.8899)=0.4107$.

${ }^{31} \exp (-0.8899+0.5279)=\exp (-0.3620)=0.6963$.
} 
Here, the proportionality factor (the $g\left(X_{i}\right)$ in equation (2)) becomes $g\left(X_{i}, \nu\right)=\exp \left(X_{i} \beta+\nu\right)$, where $\nu$ follows a multinomial distribution, with $\nu_{1}$ normalized to zero and each other $\nu_{m}$ taking on a different positive value. Equation (4) thus shows that individual $i$ contributes his expected contribution to the likelihood function. Imposing the assumptions that $M=2$ and that the baseline hazard is of a piecewise constant form, we define

$$
\begin{aligned}
d_{i}^{j} & =1 & & \text { if } d_{i}=1 \text { and } \tau_{j-1}<t_{i} \leq \tau_{j} \\
& =0 & & \text { otherwise }
\end{aligned}
$$

for $j \epsilon\{1, \ldots, 10\}$ and

$$
\begin{array}{lll}
d_{i}^{11}=1 & \text { if } d_{i}=1 \text { and } t_{i}>\tau_{10} \\
d_{i}^{11}=0 & \text { if } d_{i}=0 .
\end{array}
$$

We can then write the estimable likelihood function

$$
\begin{aligned}
L\left(t_{i} \mid d_{i}, X_{i}\right)= & P(\nu=0)\left(e^{\left(X_{i} \beta\right) d_{i}}\right) \prod_{j=1}^{11} \theta_{j}^{d_{i}^{j}} \\
& \exp \left[e^{X_{i} \beta}\left(\sum_{j=1}^{10} \mathbf{1}_{\tau_{j-1}<t_{i}} \theta_{j}\left(\tau_{j-1}-t_{i}^{d_{i}^{j}} \tau_{j}^{1-d_{i}^{j}}\right)+\mathbf{1}_{t_{i}>\tau_{10}}\left(t_{i}-\tau_{10}\right) \theta_{11}\right)\right] \\
+ & P(\nu=\bar{\nu})\left(e^{\left(X_{i} \beta+\bar{\nu}\right) d_{i}}\right) \prod_{j=1}^{11} \theta_{j}^{d_{i}^{j}} \\
& \exp \left[e^{X_{i} \beta+\bar{\nu}}\left(\sum_{j=1}^{10} \mathbf{1}_{\tau_{j-1}<t_{i}} \theta_{j}\left(\tau_{j-1}-t_{i}^{d_{i}^{j}} \tau_{j}^{1-d_{i}^{j}}\right)+\mathbf{1}_{t_{i}>\tau_{10}}\left(t_{i}-\tau_{10}\right) \theta_{11}\right)\right],
\end{aligned}
$$

where the value of $\bar{\nu}$ and the probability $P(\nu=0)$ are additional parameters to be recovered.

Table 6 shows that there is indeed unobserved heterogeneity that matters for transitions to stable private sector jobs, but the main conclusions concerning the relative impact of having an engineering degree and the role of the 2006 reform still hold (with one caveat). Columns (1) and (3) reproduce the results from tables 4 and 5 from the piecewise constant columns, and columns (2) and (4) present comparable specifications but controlling for unobserved heterogeneity as in equation (5). The hypothesis test of the estimate of $P(\nu=0)$ is with respect to a null of $P(\nu=0)=0.5^{32}$, whereas a Wald test of the null $\bar{\nu}=0^{33}$, which would correspond to an absence of unobserved heterogeneity, is rejected at the ten percent level for exits to private sector stable jobs. Although the point estimates change when controlling for unobserved heterogeneity, especially when looking at transitions to stable jobs in the private sector, the dif-

\footnotetext{
${ }^{32}$ The distribution of the estimator presented in the table is calculated by applying the delta method using a logistic transformation of the estimated underlying parameter.

${ }^{33}$ Note that we do not constrain $\bar{\nu}$ to be positive and the maximum likelihood estimator of $\bar{\nu}$ is asymptotically normal, so the conditions under which one can apply a Wald test hold in this context. Alternatively, a likelihood ratio test for the presence of unobserved heterogeneity, effectively comparing column 1 with column 2 or column 3 with column 4 of table 6 is also rejected at the 1 percent level for transitions to all stable jobs and to stable private sector jobs.
} 
ferences in coefficients between columns (3) and (4) are not significant. The only conclusion that is altered based on the inclusion of unobserved heterogeneity is related to $\mathrm{PhD}$ - Engineer Field graduates, who are no longer significantly faster than engineers in the 2006-2008 period ( $\mathrm{P}$-value $=0.1075$ with unobserved heterogeneity versus $\mathrm{P}$-value $=0.0001$ without $)$.

Table 6: Hazard Rate to a Stable Job, Piecewise Constant Baseline Hazard

\begin{tabular}{|c|c|c|c|c|}
\hline & \multirow{2}{*}{\multicolumn{2}{|c|}{$\begin{array}{l}(1) \\
\text { All Stable Jobs }\end{array}$}} & \multirow{2}{*}{\multicolumn{2}{|c|}{$\begin{array}{l}(3) \\
\text { Private Sector Only }\end{array}$}} \\
\hline & & & & \\
\hline & $\begin{array}{c}\text { Without } \\
\text { Unobserved } \\
\text { Heterogeneity }\end{array}$ & $\begin{array}{c}\text { With } \\
\text { Unobserved } \\
\text { Heterogeneity }\end{array}$ & $\begin{array}{c}\text { Without } \\
\text { Unobserved } \\
\text { Heterogeneity }\end{array}$ & $\begin{array}{c}\text { With } \\
\text { Unobserved } \\
\text { Heterogeneity }\end{array}$ \\
\hline $\mathrm{PhD}+$ Engineer & $\begin{array}{c}-0.5523 * * * \\
(0.1643)\end{array}$ & $\begin{array}{c}-0.5972 * * * \\
(0.1727)\end{array}$ & $\begin{array}{c}-0.8587 * * * \\
(0.1977)\end{array}$ & $\begin{array}{c}-0.9201 * * * \\
(0.2093)\end{array}$ \\
\hline PhD - Engineer Field & $\begin{array}{c}-0.8899 * * * \\
(0.1272)\end{array}$ & $\begin{array}{c}-0.9477 * * * \\
(0.1346)\end{array}$ & $\begin{array}{c}-1.2835 * * * \\
(0.1494)\end{array}$ & $\begin{array}{c}-1.3657 * * * \\
(0.1627)\end{array}$ \\
\hline PhD - Other Field & $\begin{array}{c}-0.7240 * * * \\
(0.1766)\end{array}$ & $\begin{array}{c}-0.7147 * * * \\
(0.1849)\end{array}$ & $\begin{array}{c}-1.4489 * * * \\
(0.2275)\end{array}$ & $\begin{array}{c}-1.4486 * * * \\
(0.2387)\end{array}$ \\
\hline $\begin{array}{c}\text { Post } 2006 \text { Reform * } \\
\text { PhD + Engineer }\end{array}$ & $\begin{array}{c}0.2110 \\
(0.2462)\end{array}$ & $\begin{array}{c}0.1122 \\
(0.2602)\end{array}$ & $\begin{array}{c}0.0626 \\
(0.3137)\end{array}$ & $\begin{array}{l}-0.1393 \\
(0.3420)\end{array}$ \\
\hline Post 2006 Reform * & $0.5279 * * *$ & $0.4170 * *$ & $0.5448 * * *$ & 0.3399 \\
\hline $\begin{array}{l}\text { Post } 2006 \text { Reform * } \\
\text { PhD - Other Field } \\
\end{array}$ & $\begin{array}{l}-0.0575 \\
(0.2215)\end{array}$ & $\begin{array}{l}-0.1845 \\
(0.2417)\end{array}$ & $\begin{array}{l}-0.3293 \\
(0.3492)\end{array}$ & $\begin{array}{l}-0.5543 \\
(0.3780)\end{array}$ \\
\hline $\bar{\nu}$ & & $\begin{array}{c}1.8450 \\
(1.3952)\end{array}$ & & $\begin{array}{l}1.5272 * \\
(0.8050)\end{array}$ \\
\hline$P(\nu=0)($ Slow Exit $)$ & & $\begin{array}{c}0.0705 * * \\
(0.0836) \\
\end{array}$ & & $\begin{array}{c}0.1552 \\
(0.1596) \\
\end{array}$ \\
\hline $\begin{array}{l}\text { Log Likelihood } \\
\text { Weighted Equivalent }\end{array}$ & -2558 & -5406 & -2172 & -4299 \\
\hline Observations & 11,028 & 11,028 & 11,028 & 11,028 \\
\hline
\end{tabular}

Notes: See notes to table $5 .{ }^{* * *} \mathrm{p}<0.01,{ }^{* *} \mathrm{p}<0.05,{ }^{*} \mathrm{p}<0.1$.

\section{Robustness}

\subsection{Search Directed Toward R \& D Positions}

As noted in section 2.3, the career plans of PhDs when they get their degrees tend to focus on research positions, and in particular public sector research / professor positions. Although there may be many fewer of these positions available, which can be part of the reason that $\mathrm{PhDs}$ take longer to find stable jobs, it is possible that the content of human capital acquired during $\mathrm{PhD}$ 
studies may be more relevant for research and/professorial positions, giving $\mathrm{PhDs}$ an advantage over engineers when targeting this type of job. Moreover, as many public sector positions of this type require a $\mathrm{PhD}$ as a prerequisite to employment, the potential pool of research jobs for engineers without $\mathrm{PhDs}$ is likely to be smaller than that of PhDs. All of these arguments suggest that, although $\mathrm{PhDs}$ make take longer than engineers to find a stable job overall, they should be able to find stable jobs faster than engineers if attention is restricted exclusively to research positions, especially those in the public sector.

Table 7 shows the results of estimating proportional hazard models with unobserved heterogeneity and controlling for the DJD reforms, but restricting attention only to transitions into $\mathrm{R} \& \mathrm{D}$ positions ${ }^{34}$. The table focuses on positions classified as R \& D in France's occupational classification system ${ }^{35}$, with and without professors included among R \& D positions, as well as positions in which the person's activities on the job are related to research and development $^{36}$. This alternative means of identifying $R \& D$ positions is only available for private sector positions in the Génération 2004 survey, but it is necessary because it is unclear, even within the French government ${ }^{37}$, whether an individual's eligibility for the CIR is a function of the official classification of his or her position or the activities he or she performs. Furthermore, it is worth noting that there are relatively few stable R \& D positions occupied within our sample window, and thus identification of these models, in particular the distributions of unobserved heterogeneity, is more fragile than when considering all stable jobs or all stable jobs in the private sector. Moreover, the very limited number of observed exits to R \& D classification positions after 2008 makes it impossible to identify an indicator to distinguish time after the 2008 DJD reform from time after the 2006 reform, so the two are grouped together in a single indicator. Finally, it is also impossible to identify the interaction of transitions to $\mathrm{R} \& \mathrm{D}$ classification positions without professors for $\mathrm{PhDs}$ in other fields after 2006, so this indicator is also suppressed from all corresponding estimations.

\footnotetext{
${ }^{34} \mathrm{As}$ is typical in a competing risks framework, if a different sort of stable job is found before an R \& D position, the time to transition into an $\mathrm{R} \& \mathrm{D}$ job is considered to be censored at the date the other stable job begins.

${ }^{35}$ Classifications considered to be $\mathrm{R} \& \mathrm{D}$ include the following codes: 383A (R \& D engineers and professionals in electricity, electronics - Ingénieurs et cadres d'étude recherche et développement en électricité électronique), 384A ( $\mathrm{R} \& \mathrm{D}$ engineers and professionals in mechanics and metalworking - Ingénieurs et cadres d'étude recherche et développement en mécanique et travail des métaux), 385A ( $\mathrm{R} \& \mathrm{D}$ engineers and professionals in processing industries (food production, chemistry, metallurgy, heavy materials) - Ingénieurs et cadres d'étude recherche et développement des industries de transformation (agroalimentaire, chimie, métallurgie, matériaux lourds)), 386A ( $\mathrm{R} \& \mathrm{D}$ engineers and professionals in other industries (printing, soft materials, furniture and wood, energy, water) - Ingénieurs et cadres d'étude recherche et développement des autres industries (imprimerie, matériaux souples, ameublement et bois, énergie, eau)), et 388A (R \& D engineers and professionals in information technology - Ingénieurs et cadres d'étude recherche et développement en informatique).

${ }^{36} \mathrm{~A}$ job is considered to be an $\mathrm{R} \& \mathrm{D}$ position using this definition when the individual described his or her activities at hiring as "Studies, Research and Development, Methods" (Etudes, Recherche et développement, méthodes) in the Génération 2004 survey.

${ }^{37}$ Interviews with program administrators from the Ministry of Finance (Direction de Trésor) and the Ministry of Higher Education and Research, July 10, 2015.
} 
Table 7: Hazard Rate to a Stable Job Classified as R \& D, Piecewise Constant Baseline Hazard

\begin{tabular}{|c|c|c|c|c|c|c|}
\hline & (1) & (2) & (3) & (4) & (5) & (6) \\
\hline & \multicolumn{3}{|c|}{ All Stable Jobs } & \multicolumn{3}{|c|}{ Private Sector Only } \\
\hline & $\mathrm{R} \& \mathrm{D}$ & $\mathrm{R} \& \mathrm{D}$ & & \multicolumn{3}{|c|}{ R \& D } \\
\hline & Classification & Classification & & Classification & Classification & \\
\hline & Without Professors & With Professors & R \& D Activities & Without Professors & With Professors & R \& D Activities \\
\hline \multirow[t]{2}{*}{$\mathrm{PhD}+$ Engineer } & -0.6183 & $0.6063 *$ & -0.2170 & -0.6122 & -0.4198 & -0.2632 \\
\hline & $(0.4718)$ & $(0.3580)$ & $(0.3963)$ & $(0.4753)$ & $(0.4660)$ & $(0.4120)$ \\
\hline \multirow[t]{2}{*}{$\mathrm{PhD}$ - Engineer Field } & $-1.6778 * * *$ & 0.2946 & $-0.9028 * * *$ & $-1.7088 * * *$ & $-0.8845^{* *}$ & $-0.9155 * * *$ \\
\hline & $(0.4486)$ & $(0.3150)$ & $(0.3335)$ & $(0.4576)$ & $(0.3932)$ & $(0.3451)$ \\
\hline \multirow[t]{2}{*}{ PhD - Other Field } & $-3.2415 * * *$ & $0.7647^{*}$ & $-2.1475 * * *$ & $-3.2331 * * *$ & -0.6887 & $-2.1261 * * *$ \\
\hline & (1.1029) & $(0.4441)$ & $(0.6674)$ & $(1.1046)$ & $(0.5920)$ & $(0.6726)$ \\
\hline \multirow[t]{2}{*}{ Post 2006 Reform } & $-0.8404 * *$ & $-1.1812 * * *$ & -0.4951 & $-0.8468 * *$ & $-1.1482 * * *$ & -0.5021 \\
\hline & $(0.4057)$ & $(0.3237)$ & $(0.3387)$ & $(0.4094)$ & $(0.3774)$ & $(0.3498)$ \\
\hline \multirow{2}{*}{$\begin{array}{l}\text { Post } 2006 \text { Reform } * \\
\text { PhD + Engineer }\end{array}$} & 0.0896 & $0.7037 *$ & 0.1066 & 0.0925 & 0.6182 & -0.0589 \\
\hline & $(0.6040)$ & $(0.3993)$ & $(0.4869)$ & $(0.6042)$ & $(0.5165)$ & $(0.5272)$ \\
\hline \multirow{2}{*}{$\begin{array}{l}\text { Post } 2006 \text { Reform * } \\
\text { PhD - Engineer Field }\end{array}$} & $1.2089 * * *$ & $0.8763 * * *$ & $0.7968 * * *$ & $1.1932 * * *$ & $0.9609 * * *$ & $0.8618 * * *$ \\
\hline & $(0.4150)$ & $(0.3058)$ & $(0.3058)$ & $(0.4252)$ & $(0.3632)$ & $(0.3157)$ \\
\hline \multirow{2}{*}{$\begin{array}{l}\text { Post } 2006 \text { Reform * } \\
\text { PhD - Other Field }\end{array}$} & & -0.5155 & 0.5040 & & -0.5714 & 0.2339 \\
\hline & & $(0.4586)$ & $(0.7916)$ & & $(0.7439)$ & $(0.8437)$ \\
\hline \multirow[t]{2}{*}{$\bar{\nu}$} & $1.38 \mathrm{E}-12$ & 16.3324 & $-3.73 \mathrm{E}-11$ & $1.01 \mathrm{E}-11$ & 16.9120 & 4.33E-09 \\
\hline & $(1.8147)$ & $(527.9430)$ & $(1.8641)$ & $(1.8648)$ & $(834.0414)$ & $(1.4629)$ \\
\hline \multirow{2}{*}{$P(\nu=0)($ Slow Exit $)$} & 0.0964 & 0.3869 & 99993.41 & 0.0958 & 0.5056 & 0.2319 \\
\hline & 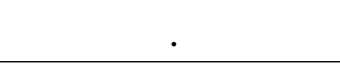 & $(0.0688)$ & $(281318.6)$ & 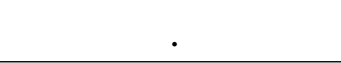 & $(0.0793)$ & 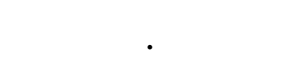 \\
\hline Log Likelihood & -855.1 & -1857 & -1332 & -837.3 & -1190 & -1259 \\
\hline Weighted Equivalent Observations & 10,872 & 10,872 & 10,872 & 10,872 & 10,872 & 10,872 \\
\hline
\end{tabular}

Notes: See notes to table 5. $* * * \mathrm{p}<0.01, * * \mathrm{p}<0.05, * \mathrm{p}<0.1$. 
The advantage of engineers over PhDs changes significantly when restricting one's attention to $\mathrm{R} \& \mathrm{D}$ positions. Engineers no longer found $\mathrm{R} \& \mathrm{D}$ positions faster than $\mathrm{PhD}+$ engineers, and found stable positions more slowly than $\mathrm{PhD}+$ engineers prior to the reforms when including the public sector and professor positions (P-value=0.0903). In fact, when considering stable $\mathrm{R} \& \mathrm{D}$ positions including professors, there is no significant difference between engineers and $\mathrm{PhD}$ - engineer field graduates prior to 2006 , and $\mathrm{PhD}$ - other field graduates find their jobs faster during this period ( $\mathrm{P}$-value $=0.0851$ ). The fact that $\mathrm{PhDs}$ do not find their stable $\mathrm{R} \& \mathrm{D}$ jobs in the private sector even more rapidly than in the public sector despite the presence of the DJD (which only benefits private sector employers) is further evidence of directed search by $\mathrm{PhDs}$, as they are not more willing to take a private sector research position, despite the possibility of being more highly paid thanks to the wage subsidy (and the likelihood that the private sector offers more job opportunities), than they are to take a public sector professorial research position.

When focusing on those who found their first stable job in R \& D after 2006, it becomes clear that the reform significantly increased the hazard rate for $\mathrm{PhD}$ - engineer field graduates, regardless of the type of employer (public or private), whether $\mathrm{R} \& \mathrm{D}$ is defined by classification or activity, and whether professors are included or not. In fact, $\mathrm{PhD}$ - engineer field graduates found their first stable R \& D-classified job (including professors) significantly faster than engineers after the 2006 reform $(\mathrm{P}$-value=0.0042). Interestingly, unobserved heterogeneity does not affect transitions into stable R \& D positions, as none of the estimated mass points $(\bar{\nu})$ are significantly different from zero.

\subsection{Endogenous Education}

Part of the reason that engineers find stable jobs sooner than $\mathrm{PhD}$ (when not focusing exclusively on R \& D jobs) may be that they have unobservable characteristics associated with faster job finding. This may be due to the school they attend, as would be the case if, for example, alumni networks from engineering schools were better at placing students than those of $\mathrm{PhD}$ programs or if hiring graduates from a particular engineering school was considered "prestigious" and employers valued this prestige separately from any underlying differences in the productivity of the person being hired. It could also be due to selection of particular students by the schools, which could occur if students who are best able to convincingly reproduce knowledge were both more likely to be accepted to engineering school and more likely to receive a job offer after being given an interview. The choice of the level of education and the field of study could also be related to unobservable characteristics that influence the speed at which people find a stable job. The presence of such endogeneity could bias the estimates of the impact of the degree on the rate at which individuals find stable jobs, and the approach to handling unobserved heterogeneity presented in section 4.3 does not allow for the distribution of unobserved heterogeneity to be correlated with the type of degree (engineer or one of the 
$\mathrm{PhD}$ types).

As it can be shown that one cannot allow Heckman and Singer (1984b) type unobserved heterogeneity to be correlated with observable variables and identify both the effects of the correlated observable variables and the conditional distribution of the the unobserved heterogeneity ${ }^{38}$, we adopt an instrumental variables approach (Bijwaard, 2009) to handling the endogeneity of education $^{39}$. However, as we only have three instruments ${ }^{40}$, we are underidentified for all models that interact the degree categories with other variables. As such, the results presented in this section are comparable to those in table 4 . The instrumental variables approach we adopt here allows us to purge our results of the bias induced by the presence of unobserved heterogeneity that induces a correlation between degrees and the time to the first stable job. By comparing the instrumented and non-instrumented results, we can draw conclusions about the distribution of unobserved heterogeneity for each education level insofar as it affects the speed at which the person finds a job.

Table 8 shows the results of estimating the instrumental variables model $^{41}$ in comparison to models in which the various degrees are treated as exogenous, i.e. columns 2 and 4 of table $4^{42}$. Although the results for $\mathrm{PhDs}$ without engineering degrees are not significantly affected by endogeneity bias, the results for engineers who continue on to complete a $\mathrm{PhD}$ are clearly biased downwards by unobserved heterogeneity. Concerning private sector jobs, controlling for endogenous education makes the distinction between engineers and engineers with $\mathrm{PhDs}$ disappear, whereas engineers with $\mathrm{PhDs}$ find stable jobs significantly faster than those without $\mathrm{PhDs}$

\footnotetext{
${ }^{38}$ See appendix D for a demonstration.

${ }^{39}$ Bijwaard (2009) shows that instrumental variables estimators have specific issues in the context of duration models with right-censored data. In particular, even when the instrument is unrelated to the unobservables that determine the outcome, its correlation with the endogenous variable implies that it can be correlated with the probability of censoring, which could invalidate the instrument if certain observations with durations close to the censoring date were considered as exits in the likelihood function. He proposes imposing an adjusted censoring duration (treating some observed observations as if they were censored) that is a function of treatment status and the model parameters that are to be recovered in the estimation. Appendix E describes how we apply this adjustment.

${ }^{40}$ Our choice of instruments was limited by the available data but aimed to capture variables that could determine the likelihood of going to an engineering school and potentially the field of study but, conditional on the individual's ability as measured by the other covariates of the model (baccalauréat results, grade skipping or repetition) and other factors (such as parent's occupations), would not be related to the time it took to find a stable job. We eventually settled on instruments based on applications to direct-acceptance engineering schools and schools that prepare students for admission exams to "higher schools" (classes préparatoires) at the end of high school. These variables should affect the type of education eventually obtained but, conditional on the various measures of pre-tertiary educational performance already included among the model regressors, they should be independent of the time it took the individual to find a stable job at least 3 years later. In particular, we use variables that identify whether the person only applied to preparatory schools, only applied to direct-acceptance engineering schools and applied to preparatory schools and direct-acceptance engineering schools (the reference category being that the individual did not apply to preparatory schools or direct-acceptance engineering schools).

${ }^{41}$ Results from the first stage (multinomial logit) instrumenting equations, along with statistical tests for instrument strength, are presented in appendix F. Due to the presence of three endogenous variables and three instruments, the model is just identified and it is impossible to present overidentification tests.

${ }^{42}$ Standard errors are corrected using the method proposed by Murphy and Topel (1985). See appendix G for details.
} 
when public sector jobs are included. These results, combined with the results in columns 1 and 2, suggest two possible explanations. First, certain engineers may prefer research positions (Roach and Sauermann, 2010), which leads them both to target their search more narrowly (thereby excluding certain positions and reducing the speed of transition to stable jobs) and be more likely to acquire a $\mathrm{PhD}$ (which increases eligibility for many public sector professor and research positions). Second, engineers may be acting rationally when assessing their job prospects at the end of their studies when minimizing the time spent searching for stable work is their objective. If a recent engineering graduate has characteristics that are unobservable in the data (but known to him/her) which make him/her less likely to find a stable job quickly, (s)he is more likely to continue on to a $\mathrm{PhD}$. This self-selection into doctoral studies significantly shortens the time (s)he would expect to spend looking for his/her first stable job, in particular by increasing his/her chances of finding a stable job in the public sector.

Table 8: Hazard Rate to a Stable Job, Piecewise Constant Baseline Hazard With and Without Endogenous Education

\begin{tabular}{|c|c|c|c|c|}
\hline & \multirow{2}{*}{\multicolumn{2}{|c|}{$\begin{array}{cc}(1) & (2) \\
\text { Exogenous Education }\end{array}$}} & \multirow{2}{*}{\multicolumn{2}{|c|}{$\begin{array}{cc}(3) & (4) \\
\text { Endogenous Education }\end{array}$}} \\
\hline & & & & \\
\hline & All & Private & All & Private \\
\hline & Stable Jobs & Sector Only & Stable Jobs & Sector Only \\
\hline \multirow{2}{*}{$\mathrm{PhD}+$ Engineer } & $-0.4769 * * *$ & $-0.8150 * * *$ & $0.9914 * *$ & 0.7285 \\
\hline & $(0.1461)$ & $(0.1765)$ & $(0.4104)$ & $(0.4765)$ \\
\hline \multirow[t]{2}{*}{$\mathrm{PhD}$ - Engineer Field } & $-0.7085^{* * *}$ & $-1.0915 * * *$ & $-0.9884 * * *$ & $-1.1413 * * *$ \\
\hline & $(0.1180)$ & $(0.1382)$ & $(0.2784)$ & $(0.3109)$ \\
\hline \multirow[t]{2}{*}{$\mathrm{PhD}$ - Other Field } & $-0.7574 * * *$ & $-1.5578 * * *$ & -0.4326 & $-0.9993 * * *$ \\
\hline & $(0.1645)$ & $(0.2108)$ & $(0.2691)$ & $(0.3347)$ \\
\hline \multirow[t]{2}{*}{ Male } & $0.1588 * *$ & $0.1610 * *$ & 0.0489 & 0.0248 \\
\hline & $(0.0667)$ & $(0.0773)$ & $(0.0984)$ & $(0.1089)$ \\
\hline \multirow[t]{2}{*}{ School Leaving Age } & $-0.0535 * * *$ & $-0.0716^{* * *}$ & $-0.1135 * * *$ & $-0.1347 * * *$ \\
\hline & $(0.0195)$ & $(0.0234)$ & $(0.0393)$ & $(0.0445)$ \\
\hline \multirow[t]{2}{*}{ Born In France } & 0.2434 & 0.1862 & 0.1225 & 0.1292 \\
\hline & $(0.1743)$ & $(0.1936)$ & $(0.2361)$ & $(0.2532)$ \\
\hline Bac: Professional or & $-0.6028 * * *$ & $-0.5428 * *$ & $-0.8120 * *$ & $-0.6304 *$ \\
\hline Technical Track & $(0.2245)$ & $(0.2370)$ & $(0.3445)$ & $(0.3482)$ \\
\hline Baccaluréat with & $0.1223^{*}$ & 0.0801 & 0.0513 & 0.0760 \\
\hline Honorable Mention (AB) & $(0.0719)$ & $(0.0819)$ & $(0.1177)$ & $(0.1259)$ \\
\hline Baccalauréat with & $0.1714 * *$ & 0.0844 & -0.0040 & -0.0414 \\
\hline Honors (B) & $(0.0851)$ & $(0.0973)$ & $(0.1469)$ & $(0.1565)$ \\
\hline Baccalauréat with & $0.3001 * *$ & 0.0697 & -0.2160 & $-0.5507 *$ \\
\hline High Honors (TB) & $(0.1293)$ & $(0.1612)$ & $(0.2115)$ & $(0.3009)$ \\
\hline Log Likelihood & -2589 & -2198 & -65975 & -61164 \\
\hline
\end{tabular}

Notes: See notes to table $4 . * * * \mathrm{p}<0.01, * * \mathrm{p}<0.05, * \mathrm{p}<0.1$. 


\section{Conclusions}

This paper has examined the reasons why engineers find their first stable jobs faster than PhDs in France. After establishing the main stylized facts, including the fact that engineers who continue their studies to complete a $\mathrm{PhD}$ take longer to find their first stable job after leaving school than engineers who go straight to the job market after obtaining their degree, several possible explanations are proposed. These include differences in the characteristics of the students, differences in the fields of study, directed search toward public sector research positions (especially professors) and "excessive" reservation wages, perhaps due to the need for compensating differentials in order to get PhDs to accept private sector jobs.

Using proportional hazards duration models, we find empirical support for all of these explanations. Worker characteristics, both observable and unobservable, significantly affect the rate of stable job finding, and there are significant differences in observable characteristics between engineers and $\mathrm{PhDs}$, especially $\mathrm{PhDs}$ who do not already have an engineering degree. Some fields of study are associated with longer times to find a stable job, and PhDs without an engineering degree who study the same fields as $\mathrm{PhDs}$ who do have an engineering degree tend to find stable jobs faster than those who study other fields, although this result is sensitive to the type of stable job being considered (any job versus private sector-only jobs, R \& D jobs with or without professors, etc.). Differences in transition rates appear to be due largely to an advantage that engineers have over PhDs in transitions to private sector jobs, suggesting directed search is relevant. When considering the impact of a subsidy program that reduced the cost of hiring PhDs in the private sector, we find that subsidies (which could allow private sector employers to increase wage offers without seeing a decrease in profits) were associated with an increase in the speed of job finding for $\mathrm{PhDs}$ in the same fields as engineers, but who lacked a priori engineering degree. It is also worth noting that the decision to pursue a $\mathrm{PhD}$ after completing an engineering degree is found to be endogenous with respect to the speed of stable job finding in a manner that is consistent with either heterogeneity in preferences for research among engineers or students who wish to minimize the time to their first stable job and have knowledge of private (unobservable in the data) information behaving rationally in their decision to pursue a $\mathrm{PhD}$.

If policy makers wanted to shorten the (relative) time it takes for PhDs to find jobs, our results suggest several options on both the demand and supply side of the labor market. First, on the demand side, if one accepts that job search is targeting public sector professor positions, then policy makers could attempt to accelerate junior hiring for this type of position. Two policies to do this include increasing the overall supply of professor positions and working to change norms that incite $\mathrm{PhDs}$ to look for post doctoral fellowships and temporary teaching positions before being able to access stable teaching jobs. Policy makers can also consider strengthening wage subsidies as these have been shown to be effective in increasing the relative job finding 
rate of $\mathrm{PhDs}$, although this may not be the most cost-effective measure as it risks generating substantial windfall gains for firms in many cases. On the supply side, $\mathrm{PhD}$ fellowships could be reallocated toward engineer fields, since this has the potential to affect the share of students with engineer field studies among the pool of $\mathrm{PhDs}^{43}$, and these students have the best chances of finding jobs in the private sector. A final policy measure that could affect the speed of finding stable jobs would be provide extra information to students in their final years of PhD study about starting salaries in the private sector and the limited opportunities in the public sector. If there is an information problem that leads $\mathrm{PhD}$ graduates to have "too high" reservation wages $^{44}$, this information could lead students to revise their reservation wages for private sector jobs and make them more likely to accept the offers they get.

\footnotetext{
${ }^{43}$ The literature on the determinants of the choice of field of study is relatively limited, so it is difficult to assess how large of an effect this might be. See Altonji et al. (2012, 2014); Beffy et al. (2012) for examples.

${ }^{44}$ The estimated effects of the DJD in section 4.2 are consistent with either a correctly defined reservation wage and a compensating wage differential - in which case the current rate of stable job finding in the private sector is individually optimal - or unrealistic beliefs about wages, working conditions and offer arrival rates in the private and public sector.
} 


\section{References}

Aliaga, C., B. Duplouy, S. Jugnot, P. Rouaud, And F. RyK (2010): "Enquête "Génération 2004"; Méthodologie et bilan," Céreq Net.Doc 63, Céreq.

Altonji, J. G., E. Blom, And C. Meghir (2012): "Heterogeneity in Human Capital Investments: High School Curriculum, College Major, and Careers," NBER Working Papers 17985, National Bureau of Economic Research, Inc.

Altonj, J. G., L. B. KAhn, AND J. D. Speer (2014): “Cashier or Consultant? Entry Labor Market Conditions, Field of Study, and Career Success," NBER Working Papers 20531, National Bureau of Economic Research, Inc.

Becker, G. S. (1993): Human Capital: A Theoretical and Empirical Analysis with Special Reference to Education, Chicago: NBER, third ed.

Beffy, M., D. Fougère, And A. Maurel (2012): "Choosing the Field of Study in Postsecondary Education: Do Expected Earnings Matter?" The Review of Economics and Statistics, 94, 334-347.

Bernela, B., L. Bonnal, C. Bonnard, J. Calmand, and J.-F. Giret (2017): “Une évaluation des effets du Dispositif Jeunes Docteurs sur l'accès aux emplois de R\&D,” Tech. rep., France Stratégie.

BijwaARD, G. E. (2009): Instrumental Variable Estimation for Duration Data, Springer Netherlands, vol. 23 of The Springer Series on Demographic Methods and Population Analysis, 111-148.

Bozio, A., D. IRAC, AND L. Py (2014): "Impact of Research Tax Credit on R \& D and Innovation: Evidence from the 2008 French Reform," Document de travail 532, Banque de France.

Cox, D. R. (1972): "Regression Models and Life-Tables," Journal of the Royal Statistical Society. Series B (Methodological), 34, 187-220.

Giraud, L., L. Miotti, J. QuÉmÉner, And M. Ros A (2014): Développement et impact du crédit d'impôt recherche : 1983-2011, Ministère de l'Education Nationale, de Enseignement Supérieur et de la Recherche.

Heckman, J. J. And B. Singer (1984a): "The Identifiability of the Proportional Hazard Model," Review of Economic Studies, 51, 231-41.

(1984b): "A method for minimising the impact of distributional assumptions in econometric models for duration data," Econometrica, 52, 271-320. 
LAnCASTER, T. (1990): The Econometric Analysis of Transition Data, Econometric Society Monographs, Cambridge, MA: Cambridge University Press.

Margolis, D. N. And L. Miotti (2015): "Évaluation de l'impact du dispositif «jeunes docteurs» du crédit d'impôt recherche," Rapport, Ministère de l'Education nationale, de l'Enseignement supérieur et de la Recherche.

MARGOLIS, D. N. AND S. YASSIN (2017): Les accidents de carrière, Sécuriser l'emploi, Paris: Les Presses de Sciences Po.

MINCER, J. A. (1974): Schooling, Experience, and Earnings, NBER Books, Cambridge, MA: National Bureau of Economic Research.

Murphy, K. M. AND R. H. Topel (1985): "Estimation and Inference in Two-Step Econometric Models," Journal of Business \& Economic Statistics, 3, 370-79.

Roach, M. And H. Sauermann (2010): “A taste for science? PhD scientists' academic orientation and self-selection into research careers in industry," Research Policy, 39, 422434.

Wright, R., P. Kircher, B. JulÎEn, And V. Guerrieri (2017): "Directed Search: A Guided Tour," NBER Working Papers 23884, National Bureau of Economic Research, Inc. 


\section{A The CEREQ Génération 2004 Survey}

The analysis is based on data drawn from the Génération 2004 Survey produced by the CEREQ ${ }^{45}$. This data follows people who graduated from the educational system between November 2003 and July 2009. The survey measures the characteristics of an individual during his or her studies and during the 5 years that follow their leaving school. Several reforms to the DJD program took place during the period covered by the survey (see section 2.4), which allows us to estimate the impact of changes to the program. From an initial sampling frame of 403,476 individuals, the final sample was comprised of 65,389 completed, valid questionnaires. Before data cleaning, this included 924 engineers and 1,830 PhDs (of which 246 also had an engineering degree).

The Génération 2004 survey, and its follow-up survey Génération 2004 à 5 ans covers initial school leavers from the 2003-2004 academic year. Those who had previously left school for more than a year and then returned were not considered initial school leavers, and were thus ineligible for sampling. All levels of the educational system were sampled.

More precisely, the eligibility criteria for the sample were as follows:

- Be enrolled in an educational institution in metropolitan France during the 2003-2004 academic year;

- Have left school between October 2003 and October 2004;

- Have never interrupted studies for a year or more prior to the 2003-2004 academic year (except for health reasons);

- Have not resumed studies during the year that followed initial school leaving;

- Be no older than 35 years old in 2004;

- Reside in metropolitan France at the time of the survey (thus excluding those who continue their studies or find a job overseas).

Among the CEREQ's regular surveys, only the 2004 wave allows one to distinguish $\mathrm{PhDs}$ that already have an engineering degree from other $\mathrm{PhDs}$, which allows one to undertake a more careful analysis of the school-to-work transition of doctors and its determinants. The other waves of the CEREQ surveys available in 2014 only collected information on the last degree obtained, which makes identification of $\mathrm{PhD}+$ Engineers impossible.

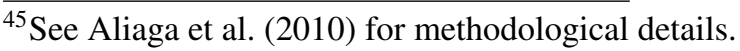


B List of Engineer Fields 
Table B.1: Fields of PhD Study Chosen and Not Chosen by Engineers

PhD Fields Chosen by Engineers

Biochemistry (Chimie-Biologie, biochimie)

Chemistry (Chimie)

Computer Science (Informatique, traitement de l'information, réseaux de transmission des données)

Earth Sciences (Sciences de la terre)

Economics (Économie)

Electricity and Electronics (Électricité, électronique)

Energy, climate engineering (Énergie, génie climatique)

Fundamental Industrial Technologies (Technologies industrielles fondamentales)

General and Precision Mechanics (Mécanique générale et de précision, usinage)

Geography (Géographie)

Health (Santé)

Industrial Transformation Technology (Technologies de commandes des transformations industrielles)

Life Sciences (Sciences de la vie)

Mathematics (Mathématiques)

Mining, Civil Engineering and Topography (Mines et carrières, génie civil, topographie)

Multi-Scientific and Multi-Technological Fields (Spécialités pluri-scientifiques, pluritechnologiques)

Natural Sciences (Biology-Geology) (Sciences naturelles (biologie-géologie))

Physics (Physique)

Physics and Chemistry (Physique-chimie)

Urban Development (Aménagement du territoire, développement, urbanisme)
$\mathrm{PhD}$ Fields Not Chosen by Engineers

Agricultural Production, Specialized Cultures and

Agricultural Protection (Productions végétales, cultures spécialisées et protection des cultures)

Business and Sales (Commerce, vente)

Culture, Sports and Leisure (Animation culturelle, sportive et de loisirs)

Finance, Banking and Insurance (Finances, banque, assurances)

Food and Cooking (Agro-alimentaire, alimentation, cuisine)

French Literature and Civilization (Français, littérature et civilisation française)

History (Histoire)

Languages and Ancient Civizations (Langues et civilisations anciennes)

Law, Political Science (Droit, sciences politiques)

Linguistics (Linguistique)

Modern Languages, Foreign and Regional Civilizations (Langues vivantes, civilisations étrangères et régionales)

Multidisciplinary Agriculture and Agronomic Fields (Spécialités plurivalentes de l'agronomie et de l'agriculture)

Mulitdisciplinary Literary and Artistic Fields (Spécialités littéraires et artistiques plurivalentes) Multidisciplinary Social Sciences and Law Fields (Spécialités pluridisciplinaires SH et droit)

Multidisciplinary Trade and Management Fields (including general business administration and public administration) (Spécialités plurivalentes des échanges et de la gestion (y c. administration générale des entreprises et des coll.))

Music, Performing Arts (Musique, arts du spectacle)

Other Multi-disciplinary Artistic Fields (Autres disciplines artistiques plurivalentes)

Philosophy, Ethics and Theology (Philosophie, éthique et théologie)

Psychology (Psychologie)

Social Sciences, Including Demography and Anthropology (Sciences sociales (y c. démographie, anthropologie))

Social Work (Travail social) 


\section{Additional Descriptive Statistics}

Table C.1: Descriptive Statistics (Means of Indicator Variables)

\begin{tabular}{|c|c|c|c|c|c|}
\hline & $\begin{array}{c}\text { Overall } \\
\text { Mean }\end{array}$ & Engineers & $\begin{array}{c}\mathrm{PhD}+ \\
\text { Engineer }\end{array}$ & $\begin{array}{c}\text { PhD - } \\
\text { Engineer Field } \\
\end{array}$ & $\begin{array}{c}\text { PhD - } \\
\text { Other Field }\end{array}$ \\
\hline \multicolumn{6}{|l|}{ Region of Higher Education Institution } \\
\hline Champagne-Ardennes & 0.030 & 0.037 & 0.000 & 0.023 & 0.001 \\
\hline Picardie & 0.003 & 0.000 & 0.000 & 0.006 & 0.011 \\
\hline Haute-Normandie & 0.008 & 0.007 & 0.000 & 0.010 & 0.010 \\
\hline Centre & 0.038 & 0.043 & 0.009 & 0.035 & 0.018 \\
\hline Basse-Normandie & 0.020 & 0.024 & 0.010 & 0.016 & 0.003 \\
\hline Bourgogne & 0.014 & 0.010 & 0.009 & 0.023 & 0.015 \\
\hline Nord-Pas de Calais & 0.078 & 0.096 & 0.028 & 0.055 & 0.035 \\
\hline Lorraine & 0.055 & 0.067 & 0.025 & 0.040 & 0.016 \\
\hline Alsace & 0.038 & 0.040 & 0.106 & 0.035 & 0.019 \\
\hline France Comté & 0.017 & 0.019 & 0.007 & 0.015 & 0.002 \\
\hline Pays de la Loire & 0.050 & 0.054 & 0.029 & 0.048 & 0.022 \\
\hline Bretagne & 0.027 & 0.016 & 0.041 & 0.046 & 0.031 \\
\hline Poitou-Charentes & 0.027 & 0.026 & 0.034 & 0.030 & 0.018 \\
\hline Aquitaine & 0.044 & 0.041 & 0.014 & 0.049 & 0.048 \\
\hline Midi-Pyrénées & 0.044 & 0.042 & 0.047 & 0.052 & 0.022 \\
\hline Limousin & 0.014 & 0.016 & 0.000 & 0.013 & 0.003 \\
\hline Rhone-Alpes & 0.121 & 0.126 & 0.136 & 0.109 & 0.133 \\
\hline Auvergne & 0.043 & 0.054 & 0.010 & 0.030 & 0.010 \\
\hline Languedoc-Roussillon & 0.039 & 0.027 & 0.034 & 0.058 & 0.053 \\
\hline PACA & 0.074 & 0.057 & 0.123 & 0.093 & 0.122 \\
\hline Corse & 0.001 & 0.000 & 0.003 & 0.001 & 0.003 \\
\hline \multicolumn{6}{|l|}{ Father's Occupation } \\
\hline Farmer & 0.021 & 0.028 & 0.011 & 0.008 & 0.015 \\
\hline Blue Collar & 0.057 & 0.071 & 0.049 & 0.039 & 0.020 \\
\hline Low-Level Employee & 0.082 & 0.098 & 0.025 & 0.064 & 0.039 \\
\hline Technician, Supervisor, Intermediate Profession & 0.096 & 0.117 & 0.101 & 0.064 & 0.050 \\
\hline Manager, Engineer, Professional, Professor & 0.429 & 0.422 & 0.385 & 0.453 & 0.379 \\
\hline Artisan, Self-Employed, Owner & 0.080 & 0.089 & 0.042 & 0.069 & 0.069 \\
\hline Do not know & 0.011 & 0.014 & 0.005 & 0.007 & 0.004 \\
\hline \multicolumn{6}{|l|}{ Mother's Occupation } \\
\hline Farmer & 0.008 & 0.011 & 0.009 & 0.002 & 0.009 \\
\hline Blue Collar & 0.031 & 0.037 & 0.010 & 0.026 & 0.003 \\
\hline Low-Level Employee & 0.275 & 0.324 & 0.117 & 0.224 & 0.111 \\
\hline Technician, Supervisor, Intermediate Profession & 0.054 & 0.058 & 0.077 & 0.045 & 0.048 \\
\hline Manager, Engineer, Professional, Professor & 0.248 & 0.245 & 0.313 & 0.240 & 0.300 \\
\hline Artisan, Self-Employed, Owner & 0.022 & 0.027 & 0.032 & 0.013 & 0.008 \\
\hline Do not know & 0.008 & 0.009 & 0.000 & 0.008 & 0.012 \\
\hline
\end{tabular}

Source: Génération 2004 and authors' calculations. 


\section{Non-identification of the Proportionality Factor and the Conditional Unobserved Heterogeneity Distribution in Heck- man and Singer (1984a) Models}

Consider a parametric proportional hazards duration model with Heckman and Singer (1984a) unobserved heterogeneity. Let the time to exit be denoted $t$, observable variables be divided into variables uncorrelated with the unobserved heterogeneity $(\boldsymbol{X})$ and those correlated with the unobserved heterogeneity $(\boldsymbol{Z})$, and unobserved heterogeneity as $\alpha$. We introduce the correlation with observables by allowing the distribution of $\alpha$ to be a function of $Z$, i.e. we write $f_{\alpha}(a \mid \boldsymbol{Z}=z)$.

Given this notation, we can write the hazard function as

$$
\lambda(T=t \mid \boldsymbol{X}=x, \boldsymbol{Z}=z, \alpha=a)=\lambda_{0}(t) g(x, z) a
$$

Integrating out the unobserved heterogeneity with respect to its distribution, we get

$\lambda(T=t \mid \boldsymbol{X}=x, \boldsymbol{Z}=z)=\lambda_{0}(t) g(x, z) \int a f_{\alpha}(a \mid \boldsymbol{Z}=z) d \alpha=\lambda_{0}(t) g(x, z) \mathbb{E}(\alpha \mid \boldsymbol{Z}=z)$.

Note that an absence of unobserved heterogeneity implies $f_{\alpha}(a \mid \boldsymbol{Z}=z)=f_{\alpha}\left(a \mid \boldsymbol{Z}=z^{\prime}\right)=1$ when $a=1$ and 0 otherwise, $\mathbb{E}(\alpha \mid \boldsymbol{Z}=z)=1 \forall z$. We can thus write the risk ratio for different values of $\boldsymbol{Z}$ as

$$
\frac{\lambda\left(T=t \mid \boldsymbol{X}=x^{\prime}, \boldsymbol{Z}=z^{\prime}\right)}{\lambda(T=t \mid \boldsymbol{X}=x, \boldsymbol{Z}=z)}=\frac{\lambda_{0}(t) g\left(x^{\prime}, z^{\prime}\right)}{\lambda_{0}(t) g(x, z)}=\frac{g\left(x^{\prime}, z^{\prime}\right)}{g(x, z)} .
$$

This well-known result (Lancaster, 1990) demonstrates the semi-parametric identification of $g(x, z)$ in proportional hazards models without unobserved heterogeneity, since the $g(x, z)$ is identified by the hazard ratio without making any assumptions about $\lambda_{0}(t)$ when $g$ is nonconstant in its arguments. The most common application of this result further assumes $g(x, z)=$ $\exp \left(x \beta_{x}+z \beta_{z}\right)$, in which case the hazard ratio just becomes $\exp \left(\left(z^{\prime}-z\right) \beta_{z}\right)$.

This results extends easily to the case of uncorrelated unobserved heterogeneity, sometimes called "random effects", as studied by Heckman and Singer (1984a). Uncorrelated unobserved heterogeneity implies $f_{\alpha}(a \mid \boldsymbol{Z}=z)=f_{\alpha}\left(a \mid \boldsymbol{Z}=z^{\prime}\right)=f_{\alpha}(a) \forall z, z^{\prime}$, so:

$$
\lambda_{0}(t) g(x, z) \int a f_{\alpha}(a) d \alpha=\lambda_{0}(t) g(x, z) \mathbb{E}(\alpha) .
$$


and thus

$$
\frac{\lambda\left(T=t \mid \boldsymbol{X}=x^{\prime}, \boldsymbol{Z}=z^{\prime}\right)}{\lambda(T=t \mid \boldsymbol{X}=x, \boldsymbol{Z}=z)}=\frac{\lambda_{0}(t) g\left(x^{\prime}, z^{\prime}\right) \mathbb{E}(\alpha)}{\lambda_{0}(t) g(x, z) \mathbb{E}(\alpha)}=\frac{g\left(x^{\prime}, z^{\prime}\right)}{g(x, z)}
$$

and $g(x, z)$ is identified, as in the case without unobserved heterogeneity.

The presence of correlated unobserved heterogeneity that is continuous or is discrete with infinite support invalidates this result as there is no way to separately identify $g(x, z)$ and $\mathbb{E}(\alpha \mid \boldsymbol{Z}=z)$ in the risk ratio without additional assumptions. Denoting the conditional expectation of $\alpha$ as $\mathbb{E}_{z}^{\alpha}=\int \alpha f(\alpha \mid \boldsymbol{Z}=z) d \alpha$, letting $g(x, z)=\exp \left(x \beta_{x}+z \beta_{z}\right)$ and integrating out the unobserved heterogeneity, we can write the hazard as a function of observables as

$$
\begin{gathered}
\lambda(T=t \mid \boldsymbol{X}=x, \boldsymbol{Z}=z) \\
=\int \lambda(T=t \mid \boldsymbol{X}=x, \boldsymbol{Z}=z, \alpha=a) f(\alpha \mid \boldsymbol{Z}=z) d \alpha \\
=\lambda(T=t \mid \boldsymbol{X}=x, \boldsymbol{Z}=z)=\lambda_{0}(t) g(x, z) \mathbb{E}_{z}^{\alpha} \\
=\lambda_{0}(t) \exp \left(x \beta_{x}+z \beta_{z}\right) \mathbb{E}_{z}^{\alpha} \\
=\lambda_{0}(t) \exp \left(x \beta_{x}\right) \exp \left(\left[z+\frac{1}{\beta_{z}} \log \left(\mathbb{E}_{z}^{\alpha}\right)\right] \beta_{z}\right)
\end{gathered}
$$

Thus despite a common $\beta_{z}$, the introduction of correlated unobserved heterogeneity represents a shift of $z$ by the (unknown) amount $\frac{1}{\beta} \log \left(\mathbb{E}_{z}^{\alpha}\right)$ under the proportional hazards assumption. Equation D.1 implies a log hazard ratio of

$$
\begin{aligned}
& \log \left(\frac{\lambda(T=t \mid \boldsymbol{X}=x, \boldsymbol{Z}=z)}{\lambda\left(T=t \mid \boldsymbol{X}=x, \boldsymbol{Z}=z^{\prime}\right)}\right) \\
& =\log (g(x, z))-\log \left(g\left(x, z^{\prime}\right)\right)+\left(\log \left(\mathbb{E}_{z}^{\alpha}\right)-\log \left(\mathbb{E}_{z^{\prime}}^{\alpha}\right)\right) \\
& \left.=\left(x \beta_{x}+z \beta_{z}\right)-\left(x \beta_{x}+z^{\prime} \beta_{z}\right)\right)+\left(\log \left(\mathbb{E}_{z}^{\alpha}\right)-\log \left(\mathbb{E}_{z^{\prime}}^{\alpha}\right)\right) \\
& =\left(z-z^{\prime}\right) \beta_{z}+\left(\log \left(\mathbb{E}_{z}^{\alpha}\right)-\log \left(\mathbb{E}_{z^{\prime}}^{\alpha}\right)\right)
\end{aligned}
$$

When $Z$ is continuous, correlated unobserved heterogeneity implies that

$$
\frac{\partial \mathbb{E}_{z}^{\alpha}}{\partial z} \neq 0
$$

so

$$
\frac{\partial \log \left(\frac{\lambda(T=t \mid \boldsymbol{X}=x, \boldsymbol{Z}=z)}{\lambda\left(T=t \mid \boldsymbol{X}=x, \boldsymbol{Z}=z^{\prime}\right)}\right)}{\partial z}=\beta_{z}+\frac{\partial \mathbb{E}_{z}^{\alpha}}{\partial z} \neq \beta_{z},
$$

i.e. variation in $z$ is insufficient to identify $\beta_{z}$ and $\mathbb{E}_{z}^{\alpha}$ separately.

When $Z$ is discrete, correlated unobserved heterogeneity implies that there exists $z, z^{\prime}$ with 
$z \neq z^{\prime}$ such that $\mathbb{E}_{z}^{\alpha} \neq \mathbb{E}_{z^{\prime}}^{\alpha}$. If we define $\beta_{z}=\frac{\log (g(x, z))-\log \left(g\left(x, z^{\prime}\right)\right)}{z-z^{\prime}}$, by equation D.2 we have

$$
\begin{aligned}
& \frac{\log \left(\frac{\lambda(T=t \mid \boldsymbol{X}=x, \boldsymbol{Z}=z)}{\lambda\left(T=t \mid \boldsymbol{X}=x, \boldsymbol{Z}=z^{\prime}\right)}\right)}{z-z^{\prime}}=\frac{\left(z-z^{\prime}\right) \beta_{z}+\left(\log \left(\mathbb{E}_{z}^{\alpha}\right)-\log \left(\mathbb{E}_{z^{\prime}}^{\alpha}\right)\right)}{z-z^{\prime}} \\
&=\beta_{z}+\frac{\log \left(\mathbb{E}_{z}^{\alpha}\right)-\log \left(\mathbb{E}_{z^{\prime}}^{\alpha}\right)}{z-z^{\prime}} \neq \beta_{z} .
\end{aligned}
$$

Again, this implies that without additional constraints, it is impossible to separate $\beta$ from $\mathbb{E}_{z}^{\alpha}$. 


\section{E Right Censoring Adjustment for Endogenous Education}

The correction for the right censoring time is developed by Bijwaard (2009), using generalized accelerated failure time (GAFT) notation, in his appendix B, with the intuition provided in section 2.3. This approach adjusts the censoring time differently for different levels of the endogenous variable, depending on the sign of the true relation between the endogenous variable and the hazard function. Here, we generalize his result to the case of multiple endogenous variables.

Concretely, the GAFT model converts the (possibly unobserved) failure times into "transformed durations" using the observed covariates and the baseline hazard function. In the case of a proportional hazards model, these transformed durations are simply values of the integrated hazard function, which (using the notation of equation 2) gives

$$
\tilde{t}_{i} \mid X_{i}=\int_{0}^{t_{i}} h_{0}(s ; \theta) \exp \left(X_{i} \beta\right) d s .
$$

Given that we have three endogenous degree variables $(\mathrm{PhD}+$ Engineer, $\mathrm{PhD}$ - Engineer Field and $\mathrm{PhD}$ - Other Field), we divide the set of observable variables $\left(X_{i}\right)$ into exogenous variables $\left(X_{i}^{-D}\right)$ and endogenous variables $\left(D_{i}\right)$. Denoting the untransformed censoring duration as $C_{i}{ }^{46}$, equation B.7 of Bijwaard (2009) provides expressions for the transformed censoring duration $\tilde{C}_{i}\left(X_{i}, t_{i} ; \theta, \beta\right)$ as

$\tilde{C}_{i}\left(X_{i}, t_{i} ; \theta, \beta\right)= \begin{cases}\int_{0}^{C_{i}} h_{0}(s ; \theta) \exp \left(X_{i}^{-D} \beta^{-D}+\min \left(\boldsymbol{\beta}^{D}, 0\right)\right) d s & \text { if } t_{i}>C_{i} \\ \int_{0}^{t_{i}} h_{0}(s ; \theta) \exp \left(X_{i}^{-D} \beta^{-D}+\min \left(\boldsymbol{\beta}^{D}, 0\right)\right) d s+\int_{t_{i}}^{C_{i}} h_{0}(s ; \theta) d s & \text { if } t_{i} \leq C_{i}\end{cases}$

where min $\left(\beta^{D}, 0\right)$ takes the smallest value from among all of the coefficients on the endogenous variables and zero ${ }^{47}$. Note that this expression implies that when spells are right censored, no additional censoring is applied (equation E.1 will be larger than the first line of equation E.2, which implies an untransformed censoring duration no larger than $C_{i}$ ). However, when the spells are uncensored and any of the $\beta^{D}$ terms are less than zero, the first element of the second line in equation E. 2 shows that the censoring date will need to be adjusted to accommodate the slowest-exiting degree ${ }^{48}$, and that the adjustment will depend on the estimated model

\footnotetext{
${ }^{46}$ Recall that the censoring duration can vary across individuals due to variation in school leaving dates.

${ }^{47}$ Bijwaard (2009) presents a model in which there is a single endogenous variable but its coefficient can evolve over the spell at fixed intervals. As we assume the coefficient is constant over the spell, the term $P(s ; \gamma)=$ $I\left(s \geq t_{k}\right) \prod_{j=0}^{k} \min \left(e^{\gamma_{j}}, 0\right)$ in his text reduces to $P(s ; \gamma)=\min \left(e^{\gamma}, 0\right)$ in our case.

${ }^{48}$ In the case of multiple endogenous variables, each endogenous variable would imply a different adjusted censuring point for the transformed duration $\tilde{t}_{i} \mid X_{i}$ in the Bijwaard (2009) formulation. Under the standard assumptions for instrument validity, the independence of the instrument and the transformed duration only holds up to the first adjusted censuring point. Beyond that, certain values of the instrument (those associated with a
} 
parameters.

In order to implement our estimation, we employed an iterative three-step estimation technique for which we bootstrap the standard errors ${ }^{49}$.

1. Estimate a multinomial logit model of educational attainment to predict the probability that each individual in our sample obtains each of the 4 possible degrees.

2. Set the censoring indicator for each individual. On the first iteration, the censoring indicator is determined by the condition $t_{i}>C_{i}$. On all later iterations, the censoring indicator is determined by the condition $\tilde{t}_{i}>\tilde{C}_{i}$.

3. Estimate the duration model of equation 1. If the mean squared difference in coefficient vectors changes by more than $10^{-4}$ go to step 2 . Otherwise, declare convergence ${ }^{50}$.

We use the correction for two-stage estimators proposed by Murphy and Topel (1985) (see appendix G) in order to recover standard error estimates of the parameters for this model.

higher probability of the corresponding slow-exiting endogenous variable) will be overrepresented, thereby violating the independence required for consistency. By imposing the earliest censoring point on all observations (corresponding to min $\left(\boldsymbol{\beta}^{D}, 0\right)$ ), one ensures independence over the full set of durations that contribute to the estimation of the likelihood function, with all longer durations simply contributing the survivor function at the adjusted ( $X$-dependent) censoring time.

${ }^{49}$ It should be noted that Bijwaard (2009) proposes both an adjusted censoring duration and an iterative estimation approach based on applying a GMM-like technique to a linear rank estimator (LRE) to estimate the full model in his paper. In order to maintain consistency with the maximum likelihood estimation methods found elsewhere in this paper, we do not apply his GMM-like technique, as it would be impossible to determine whether changes in coefficients were due to endogeneity of education or changes in estimation methodology.

${ }^{50}$ In the event that the maximum iteration threshold (500 iterations) is reached without convergence, the estimates with the largest log likelihood are presented. 


\section{F Results from First Stage Instrumenting Equations}

Table F.1: Multinomial Logit for Educational Attainment

\begin{tabular}{|c|c|c|c|}
\hline & $\begin{array}{l}\mathrm{PhD}+ \\
\text { Engineer }\end{array}$ & $\begin{array}{c}\text { PhD - } \\
\text { Engineer Field }\end{array}$ & $\begin{array}{c}\text { PhD - } \\
\text { Other Field }\end{array}$ \\
\hline $\begin{array}{l}\text { Applied to preparatory school, } \\
\text { not engineering school }\end{array}$ & $\begin{array}{c}0.5956 \\
(0.4964)\end{array}$ & $\begin{array}{l}-0.9910^{* *} \\
(0.4296)\end{array}$ & $\begin{array}{c}-3.0688^{* *} \\
(1.3330)\end{array}$ \\
\hline $\begin{array}{l}\text { Applied to engineering school, } \\
\text { not preparatory school }\end{array}$ & $\begin{array}{l}-0.0728 \\
(0.8479)\end{array}$ & $\begin{array}{l}-1.3790^{*} \\
(0.7527)\end{array}$ & $\begin{array}{c}-7.3155 \\
(147.6249)\end{array}$ \\
\hline $\begin{array}{l}\text { Applied to preparatory school } \\
\text { and engineering school }\end{array}$ & $\begin{array}{l}-0.0095 \\
(0.6231)\end{array}$ & $\begin{array}{c}-2.0648 * * * \\
(0.5638)\end{array}$ & $\begin{array}{l}-2.0411 \\
(2.3745)\end{array}$ \\
\hline Male & $\begin{array}{l}-0.7369^{*} \\
(0.4329)\end{array}$ & $\begin{array}{l}-0.7523^{*} \\
(0.3852)\end{array}$ & $\begin{array}{l}-1.7076^{*} \\
(1.0207)\end{array}$ \\
\hline School Leaving Age & $\begin{array}{l}2.1354 * * * \\
(0.1686)\end{array}$ & $\begin{array}{l}2.1075 * * * \\
(0.1594)\end{array}$ & $\begin{array}{l}3.1975^{* * * *} \\
(0.7770)\end{array}$ \\
\hline Born in France & $\begin{array}{c}1.8684 \\
(1.2292)\end{array}$ & $\begin{array}{c}1.2761 \\
(1.0434)\end{array}$ & $\begin{array}{c}1.4801 \\
(18.2173)\end{array}$ \\
\hline $\begin{array}{l}\text { Bac: Professional or } \\
\text { Technical Track }\end{array}$ & $\begin{array}{l}-3.1982 * * \\
(1.5617)\end{array}$ & $\begin{array}{c}-3.8167 * * * \\
(1.1878)\end{array}$ & $\begin{array}{l}-11.3820 * * * \\
(3.7593)\end{array}$ \\
\hline $\begin{array}{l}\text { Baccalauréat with } \\
\text { Honorable Mention (AB) }\end{array}$ & $\begin{array}{l}1.8095 * * * \\
(0.5184)\end{array}$ & $\begin{array}{c}0.6906 \\
(0.4397)\end{array}$ & $\begin{array}{l}-0.0776 \\
(1.3745)\end{array}$ \\
\hline $\begin{array}{l}\text { Baccalauréat with } \\
\text { Honors (B) }\end{array}$ & $\begin{array}{c}2.5307 * * * \\
(0.5628)\end{array}$ & $\begin{array}{l}1.0157 * * \\
(0.4855)\end{array}$ & $\begin{array}{l}3.1733 * \\
(1.8392)\end{array}$ \\
\hline $\begin{array}{l}\text { Baccalauréat with } \\
\text { High Honors (TB) }\end{array}$ & $\begin{array}{c}2.9721 * * * \\
(0.8357)\end{array}$ & $\begin{array}{c}0.9951 \\
(0.7916)\end{array}$ & $\begin{array}{c}1.4006 \\
(2.0931)\end{array}$ \\
\hline $\begin{array}{l}\text { Observations } \\
\text { Log-likelihood }\end{array}$ & & $\begin{array}{c}2030 \\
-457.3\end{array}$ & \\
\hline $\begin{array}{l}\text { LR Test: Instruments Improve Fit } \\
\text { P-Value } \\
\text { Wald Test: Instruments Jointly Significant } \\
\text { P-Value }\end{array}$ & & $\begin{array}{c}\chi^{2}(9)=59.91 \\
0.0000 \\
\chi^{2}(9)=53.59 \\
0.0000\end{array}$ & \\
\hline
\end{tabular}

Notes: See notes to table 5. *** $\mathrm{p}<0.01, * * \mathrm{p}<0.05, * \mathrm{p}<0.1$. 


\section{G Murphy and Topel (1985) Covariance Matrix Correction for IV Duration Models}

As noted by Murphy and Topel (1985), the second stage maximum likelihood estimator of a two-step model where the first-stage equation is consistently estimated by maximum likelihood is also consistent under commonly assumed conditions, but the covariance matrix is underestimated. Following equations 29 and 34 of Murphy and Topel (1985), the correct covariance matrix for the second stage estimator (in our case, the duration model) can be written as

$$
\begin{gathered}
\Sigma=R_{2}^{-1}+R_{2}^{-1}\left[R_{3}^{\prime} R_{1}^{-1} R_{3}-R_{4}^{\prime} R_{1}^{-1} R_{3}-R_{3}^{\prime} R_{1}^{-1} R_{4}\right] R_{2}^{-1} \\
\text { with } \\
R_{1}\left(\theta_{1}\right)=E \frac{\partial \mathscr{L}_{1}}{\partial \theta_{1}}\left(\frac{\partial \mathscr{L}_{1}}{\partial \theta_{1}}\right)^{\prime}=-E \frac{\partial^{2} \mathscr{L}_{1}}{\partial \theta_{1} \partial \theta_{1}^{\prime}} \\
R_{2}\left(\theta_{2}\right)=E \frac{\partial \mathscr{L}_{2}}{\partial \theta_{2}}\left(\frac{\partial \mathscr{L}_{2}}{\partial \theta_{2}}\right)^{\prime}=-E \frac{\partial^{2} \mathscr{L}_{2}}{\partial \theta_{2} \partial \theta_{2}^{\prime}} \\
R_{3}(\theta)=E \frac{\partial \mathscr{L}_{2}}{\partial \theta_{1}}\left(\frac{\partial \mathscr{L}_{2}}{\partial \theta_{2}}\right)^{\prime}=-E \frac{\partial^{2} \mathscr{L}_{2}}{\partial \theta_{1} \partial \theta_{2}^{\prime}} \\
R_{4}(\theta)=E \frac{\partial \mathscr{L}_{1}}{\partial \theta_{1}}\left(\frac{\partial \mathscr{L}_{2}}{\partial \theta_{2}}\right)^{\prime}
\end{gathered}
$$

Note that $R_{1}\left(\theta_{1}\right)$ is the estimator of the covariance matrix from the multinomial logit (first stage) model and $R_{2}\left(\theta_{2}\right)$ is the estimator of the covariance matrix from the duration (second stage) model using the predicted values from the first stage model. The $\frac{\partial \mathscr{L}_{1}}{\partial \theta_{1}}$ and $\frac{\partial \mathscr{L}_{2}}{\partial \theta_{2}}$ parts of $R_{3}(\theta)$ and $R_{4}(\theta)$ are calculated by multiplying the $X$ matrix by the score vector of the relevant likelihood function with respect to $X \theta$. The final component, $\frac{\partial \mathscr{L}_{2}}{\partial \theta_{1}}$, is calculated by multiplying the score vector (with respect to $X_{2} \theta_{2}$, where $X_{2}$ is the matrix of $X$ variables used in the duration model) from the duration model by the coefficient vector from the duration model, and then multiplying by the derivative of each element of $X_{2}$ with respect to $\theta_{1}$ from the first stage model. This derivative is zero for all exogenous variables, and corresponds to the derivative of the predicted probability of each degree with respect to $\theta_{1}$ for each of the endogenous degrees. In the case of the multinomial logit, this is simply $\mathbb{P}($ Degree $=d)(1-\mathbb{P}($ Degree $=d)) X_{1}$, where $X_{1}$ is the matrix of $X$ variables used in the multinomial logit. 
Figure 1: Unemployment Rate of PhDs and Engineers in 2007, 3 Years After Leaving School

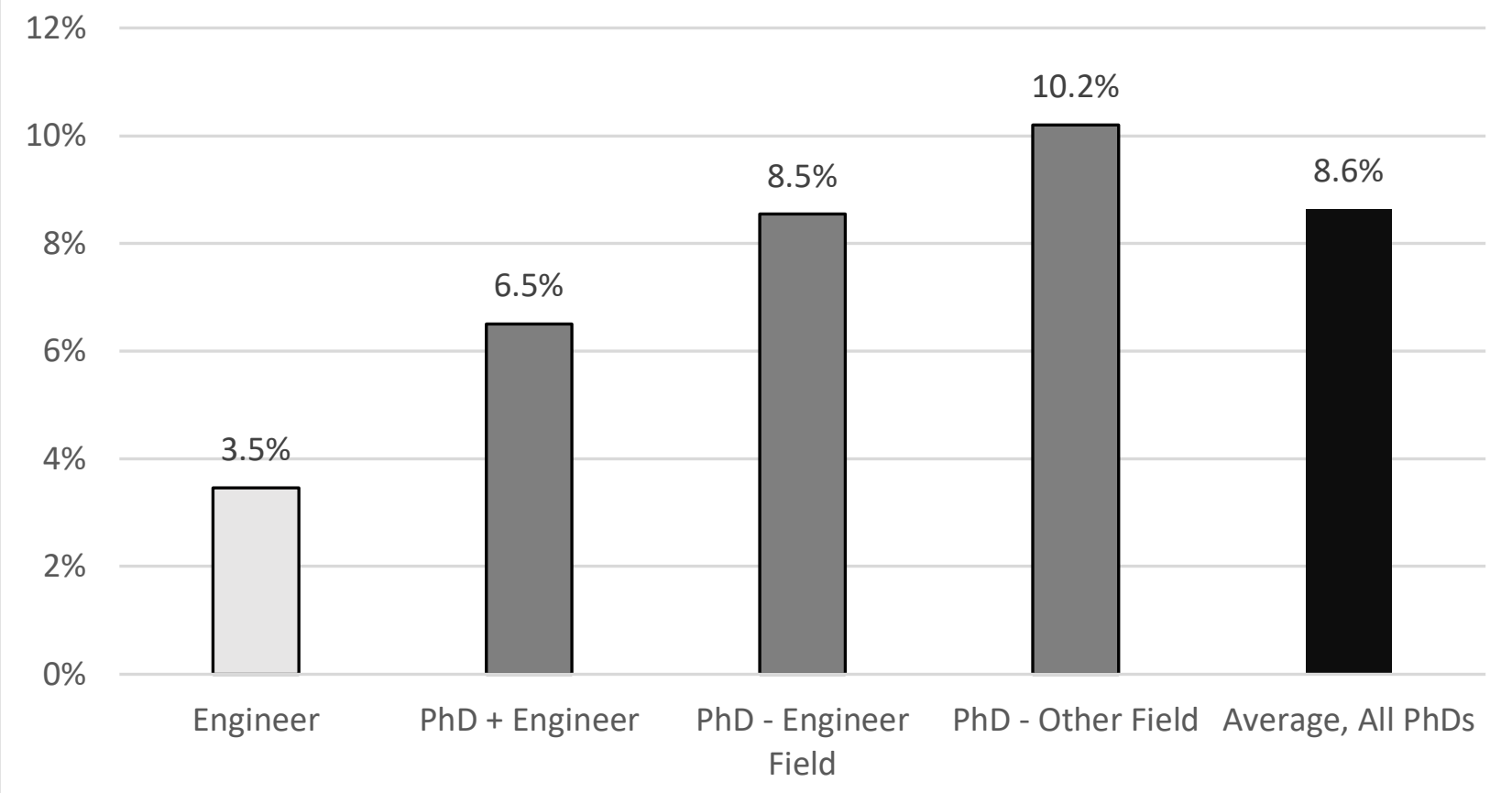


Figure 2: Time to First Stable Job Among Uncensored Observations

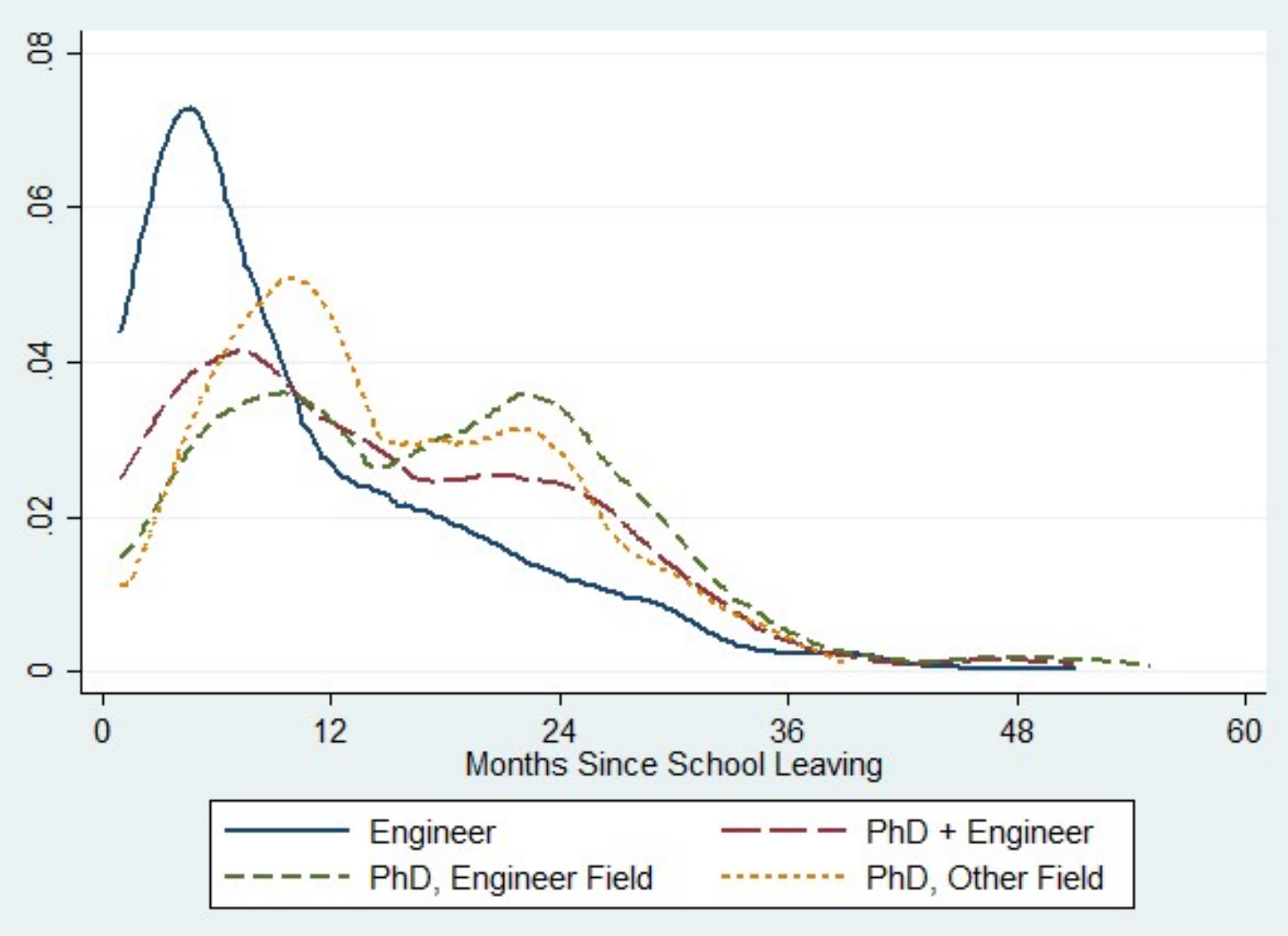

Source: Génération 2004 and authors' calculations 